\title{
THIN-LAYER CONVECTIVE DRYING BEHAVIOUR OF BRAZILIAN PEPPERTREE LEAVES
}

\author{
SECAGEM EM CAMADA DELGADA DE FOLHAS DE AROEIRA
}

\section{Pedro Amorim BERBERT ${ }^{1}$; Marcia Terezinha Ramos de OLIVEIRA ${ }^{2}$; Marília Amorim BERBERT-MOLINA ${ }^{3}$; Karina de Jesus SOARES ${ }^{4}$; Antonione Araujo COELHO}

1. Ph.D. Lecturer and Researcher, State University of Northern Rio de Janeiro - UENF, Agricultural Engineering Department - LEAG, Campos dos Goytacazes, RJ, Brazil. pberbert@uenf.br; caparao00@gmail.com; 2. Postdoctoral Scholar, UENF/LEAG, Campos dos Goytacazes, RJ, Brazil; 3. Ph.D. Lecturer and Researcher, State University of Northern Rio de Janeiro - UENF, Biotechnology Department - LBT, Campos dos Goytacazes, RJ, Brazil; 4. Ph.D. in Plant Science, UENF/LEAG, Campos dos Goytacazes, RJ, Brazil; 5. Ph.D. Candidate UENF/LEAG, Campos dos Goytacazes, RJ, Brazil.

\begin{abstract}
Studies on the drying kinetics of medicinal, aromatic and spice plants are a necessary step towards establishing the combination of drying parameters that would not qualitatively and quantitatively alter the quality of the fresh product. The purpose of this study was to investigate the drying kinetics of Brazilian peppertree (Schinus terebinthifolius) leaves and to verify whether the theoretical diffusion and the semi-empirical Lewis drying models were capable of accurately predicting the drying curves of the product at 35,40 , and $45^{\circ} \mathrm{C}$, with a dry air mass flow rate of $0.731 \mathrm{~kg} \mathrm{~s}^{-1} \mathrm{~m}^{-2}$. Leaves were collected at $0800 \mathrm{~h}, 1200 \mathrm{~h}$ and $1700 \mathrm{~h}$. The goodness of fit between experimental and predicted values was based on the correlation coefficient, root mean square error, mean absolute percentage error, mean bias error, and fit index. Residual plot analysis was also considered in the selection of the most effective drying model. Temperature had a pronounced effect on mass transfer and drying rate decreased continuously during the course of drying. Leaf collection time had little influence on the drying kinetics. Effective moisture diffusivity was found to increase with temperature. The results indicated that the Lewis model was considered a better predictor of the thin-layer drying behaviour of Brazilian peppertree leaves than the theoretical model based on Fick's second law of diffusion.
\end{abstract}

KEYWORDS: Schinus terebinthifolius Raddi. Lewis thin-layer drying model. Theoretical diffusion model. Error analysis.

\section{INTRODUCTION}

Brazilian peppertree

(Schinus terebinthifolius Raddi, Anacardiaceae), is a pioneer small to medium size tree or multi-stemmed large shrub species native to Brazil, and west to northeastern Argentina, Paraguay and Uruguay (WILLIAMS et al., 2005; Mc KAY et al., 2009. In Brazil, S. terebinthifolius is found along the Atlantic coast toward inland ecosystems up to $1200 \mathrm{~m}$ above sea level, where it is common and found virtually in any altered area (LENZI; ORTH, 2004; CERUKS et al., 2007; D'AVILA et al., 2010). S. terebinthifolius has been introduced into other South American countries, parts of Central America, Bermuda, the Bahamas, the West Indies, USA (Florida, southern Arizona, California, and Hawaii), Mediterranean Europe, North Africa, southern Asia and South Africa (MORTON, 1978). The plant was introduced into the USA sometime in the late 1890s and was originally grown as an ornamental, but $S$. terebinthifolius is nowadays considered the most widespread invasive exotic in Florida and Hawaii, where it is now found invading disturbed areas, often forming dense monotypic stands, and displaces native vegetation (EWE; STERNBERG, 2003; MORGAN; OVERHOLT, 2005).

S. terebinthifolius leaves are evergreen and thick, alternate, and have reddish, sometimes winged midribs, imparipinnately compound with 79 sessile, oblong or elliptic, finely toothed leaflets, $2.5-5.0 \mathrm{~cm}$ long. Leaves smell of turpentine when crushed. The tree produces compact clusters of spherical, resinous, one-seeded fruits (3 to $5 \mathrm{~mm}$ in diameter enclosing a single internal seed), light green, glossy and juicy at first, becoming bright red on ripening and then dark red. The red skin dries to become a papery shell surrounding the dark brown seed (MORTON, 1978; BENDAOUD et al., 2010; HALL et al., 2012). Its bright red berries and brilliant green foliage are used frequently as Christmas decorations. S. terebinthifolius is known by a variety of common names including Brazilian pepper, Christmas-berry, pink pepper, poivre rose 
(in French), aroeira-vermelha (in Portuguese), and erroneously as Florida holly (MORTON, 1978; BARBOSA et al., 2007).

Dried whole or ground S. terebinthifolius fruits are commonly used as a spice for its pungent pepper-like flavour and taste. In some countries, the fruits are used as a pepper substitute or as an adulterant of black pepper (Piper nigrum) (ElMASSRY et al., 2009; FEUEREISEN et al., 2014). Fruits are richer in essential oil (3.9 to $4.7 \%$ ) than leaves $(0.1$ to $0.9 \%)$. The essential oil yield obtained by Barbosa et al. (2007) with fresh leaves collected from branches without flowers was $0.4 \% \mathrm{w} / \mathrm{w}$, whereas with those from branches that were flowering, the amount found was reduced to $0.1 \%$ w/w. Sesquiterpenes (from $84 \%$ to $90 \%$ ) dominated the oil content. The major compounds were germacrene-B, bicyclogermacrene, $(E)$ caryophyllene, $\beta$-pinene, and $(Z)-\beta$-ocimene. The essential oil extracted by El-Massry et al. (2009) from Egyptian $S$. terebinthifolius leaves yielded $0.5 \%$ for fresh leaves and $0.9 \%$ for shade-dried leaves (w/w). Sesquiterpenes comprised $60 \%$ and $75 \%$ of the essential oil composition from fresh and dried leaves, respectively. The major compounds were cis- $\beta$-terpineol, $(E)$-caryophyllene, caryophyllene alcohol, geranyl-n-butyrate, $\beta$ cedrene, $\beta$-sesquiphellandrene, and citronellal.

$S$. terebinthifolius bark, fruit, seeds and leaves have been used in traditional medicine throughout tropical regions. The crushed, dried leaves are applied as antiseptic poultices on ulcers and leaf infusions are taken to relieve bronchitis and other respiratory ailments. Decoctions of the leaves or fruits are used to bathe wounds and sores or inhaled for hypertension and irregular heart beat. A decoction of the bark is used in baths to relieve rheumatic and back pain. Although $S$. terebinthifolius is widely used for medicinal purposes some people exposed to the tree can develop contact dermatitis, causing itching of the skin accompanied by swelling and reddening of the face and eyelids (MORGAN; OVERHOLT, 2005; El-MASSRY et al., 2009).

After decades of investigation into the drying characteristics of cereals, oilseeds and other agricultural products, the investigation of the drying behaviour of medicinal and aromatic plants has now attracted the interest of many researchers (ZANOELO et al., 2007; ARSLAN et al., 2010; CHENARBON et al., 2011). Studies on the drying kinetics of medicinal, aromatic and spice plants are a necessary step towards establishing the combination of the drying parameters that would not qualitatively and quantitatively alter the chemical components present in the fresh product. Besides, the simulation of the thin-layer drying process employing mathematical models constitutes a powerful tool to design engineers that can determine the most appropriate type of drying for a particular herb. Mathematical modelling is also useful to determine the size or optimize drying equipment and to choose the most suitable operating conditions that should be employed in commercial deep-bed driers (BLASCO et al., 2006; GUNHAN et al., 2005; OLIVEIRA et al., 2011).

It is not within the scope of the present study to develop a new mathematical model or to determine which one best describes the drying curves of $S$. terebinthifolius among the several models found in the literature, a task that will be addressed in future work. Notwithstanding, we will verify if both a theoretical drying model based on Fick's second law of diffusion (CRANK, 1975) and a simple model developed by Lewis (1921) are capable of describing, with a good degree of accuracy, the decrease in moisture of the product throughout the drying process. Although the Lewis drying model is considered not to provide acceptable results in cereal grain drying (BROOKER et al., 1992), it proved to be more than a reasonable alternative to the description of the drying of some medicinal and aromatic plants (BUSER et al., 1999; TEMPLE; van BOXTEL, 1999; PANCHARIYA et al., 2002; ZANOELO et al., 2007; DOYMAZ, 2009; THERDTHAI; ZHOU, 2009).

Our objectives in this study were to evaluate the drying kinetics of S. terebinthifolius leaves, and to verify if the theoretical diffusion and the semiempirical Lewis drying models are capable of accurately predicting the drying curves of the product at 35,40 , and $45^{\circ} \mathrm{C}$, with dry air mass flow rate of $0.731 \mathrm{~kg} \mathrm{~s}^{-1} \mathrm{~m}^{-2}$.

\section{MATERIAL AND METHODS}

\section{Plant material}

Leaves from volunteer plants of Brazilian peppertree (Schinus terebinthifolius Raddi) grown on experimental fields at the Northern Rio de Janeiro State University campus, Campos dos Goytacazes, SE Brazil, were used. Leaves used in this investigation were all collected on August 2017, starting at $0800 \mathrm{~h}, 1200 \mathrm{~h}$ and $1700 \mathrm{~h}$. Main branches containing sun leaves that were positioned at a height from 2 to $3 \mathrm{~m}$ from the ground were randomly collected from four individual trees using a tree pruner. Samples were then bagged and immediately transferred to the laboratory. Collection 
time was no longer than $0.25 \mathrm{~h}$. Upon arrival at the laboratory, all leaves were cut from the main and side branches, and leaf selection was based on size, thickness and colour. Both old and newly developing leaves were discarded. This selection process yielded three $0.150 \mathrm{~kg}$ clean subsamples of leaves with similar morphological characteristics for each drying test. Leaf thickness was measured with a digital calliper $(0.01 \mathrm{~mm}$ resolution and $\pm 0.02 \mathrm{~mm}$ accuracy) on 40 leaves (10 leaves per plant). Measurements were made at three random points per leaf and the average was used as an individual value. The mean initial moisture content of the samples ranged from 56.4 to $59.8 \%$ w.b., as determined in a forced-convection air-oven at $60^{\circ} \mathrm{C}$ for $72 \mathrm{~h}$ according to the ASABE Standard S358.2 (ASABE, 2010). The samples were subsequently distributed to three circular drying trays evenly so as to produce a single layer of the product (Figure 1). The trays were then placed in the drying chamber.

\section{Description of the thin-layer drier}

A thin-layer laboratory drier (Figure 2) was built to deliver a controlled air mass flow rate at predetermined dry-bulb temperatures to the Brazilian peppertree leaf samples. Ambient air is drawn into the drying system by a centrifugal-flow fan through a diaphragm valve which enables the air to be supplied at the required airflow. The drier is equipped with a frequency inverter connected to the fan induction motor, allowing finer control of the air flow rate. In passing through the automatically controlled resistance heater unit, the air temperature is raised and maintained within $\pm 0.5^{\circ} \mathrm{C}$ of the desired level just prior to entering the drier plenum chamber. Drying-air temperature could be adjusted to values between $30^{\circ} \mathrm{C}$ and $70^{\circ} \mathrm{C}$ through a proportional type controller.

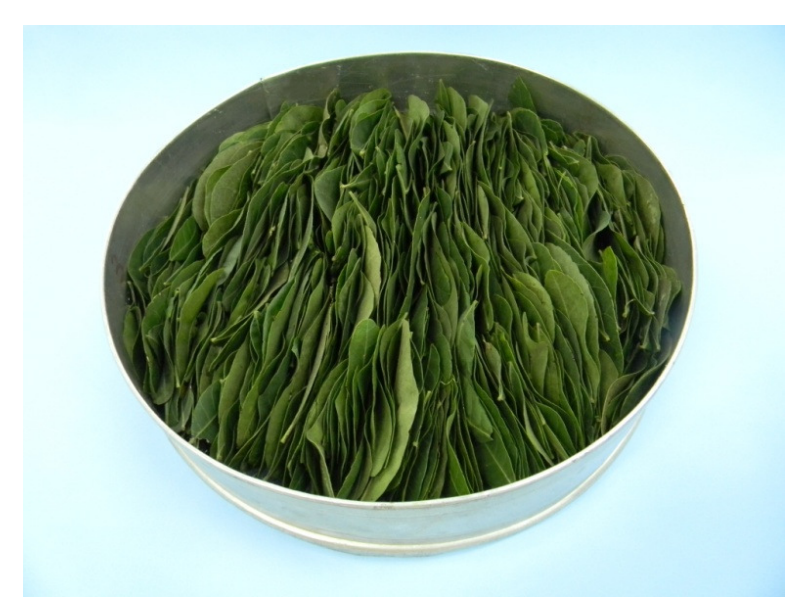

Figure 1. Circular drying tray containing a sample of Brazilian peppertree leaves.

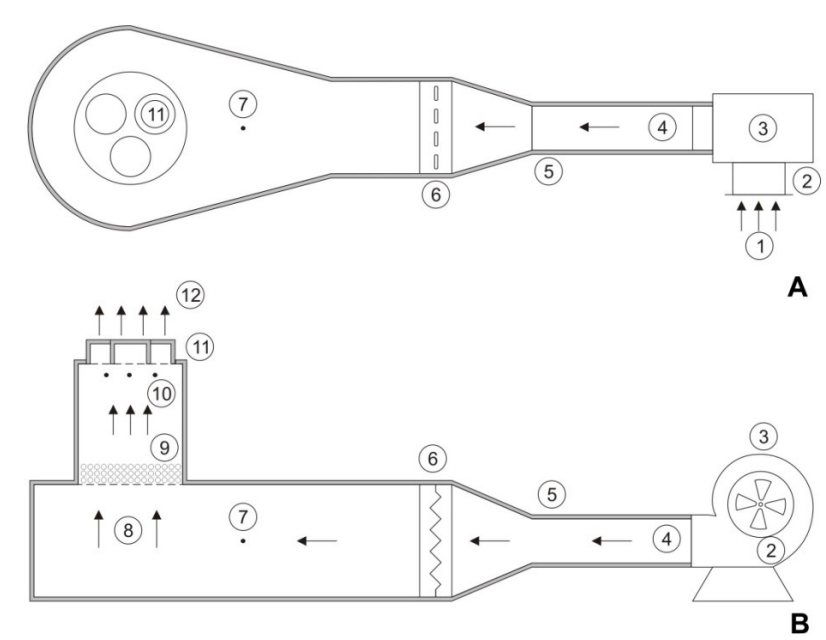

Figure 2. Diagrammatic sections of the prototype drier (top view - Figure 2A, and front view - Figure $2 \mathrm{~B}$ ). 1 . Air inlet; 2. Diaphragm valve; 3. Variable speed centrifugal-flow fan; 4. Air duct; 5. Fibreglass insulated wall; 6. Resistance heater unit; 7. Microprocessor temperature controller; 8. Plenum chamber; 9. Glass spheres; 10. Thermocouples; 11. Drying trays; 12. Air exhaust. 
The drying-air moves horizontally from the fan outlet, passes through the resistance heaters and enters the plenum chamber, and then moves upward through a vertical $0.60 \mathrm{~m}$ diameter duct until it reaches the test chamber at the upper end of the duct. The test chamber has three openings to accommodate removable circular drying trays 0.24 $\mathrm{m}$ in diameter and $0.05 \mathrm{~m}$ in height. Each drying tray has a perforated steel base, allowing the passage of the drying-air through the product with a negligible pressure drop. The base of the vertical duct that connects the plenum to the test chamber has a flow-smoothing section of $50 \mathrm{~mm}$ filled with small glass spheres $17 \mathrm{~mm}$ in diameter. The entire drier was built having a double-wall structure with a $20 \mathrm{~mm}$ gap between the inner and outer walls, and the wall cavities were filled with fibreglass insulation to facilitate temperature control by minimising heat loss to the surroundings. The surface of the Brazilian peppertree leaf bed was open to the atmosphere but shielded from draughts by a dedicated exhaust duct.

\section{Drying test procedures}

For each run, the drier was allowed at least half an hour to stabilise at the specified air temperature before the test began. The trays were placed in the drying chamber and the test was then started. Moisture content of the samples throughout the drying process was determined gravimetrically by removing the trays from the drying chamber and weighing them to an accuracy of $\pm 0.01 \mathrm{~g}$ every 5 minutes in the first 30 minutes, every 10 minutes up to 2 hours, every 15 minutes up to $31 / 2$ hours and every 30 minutes thereafter. Drying was stopped when samples reached $13.5 \%$ w.b. average moisture content. At the conclusion of each test, a sample was taken from each tray for the determination of the final moisture content (ASABE, 2010), giving a reliable cross-checking of results.

Ambient-air temperature and relative humidity were measured and recorded with a thermohygrograph located near the air input side of the drier. The recorded values were used to calculate other psychrometric properties of the drying-air (enthalpy, humidity ratio and specific volume) employing the software GRAPSI (MELO et al., 2004). The temperature of the air passing through the sample was continuously monitored with a copper-constantan thermocouple inserted $2 \mathrm{~cm}$ below the drying chamber. Another thermocouple detected the exhaust drying air temperature. The values were monitored and recorded with a data acquisition system. The air velocity measurements were made ahead of the drying chamber using a vane anemometer. Measurements were made prior to each weighing of the drying trays.

Convective mass transfer during the passage of the drying air through a thin-layer of a product is generally studied using air velocity as the main parameter associated with air movement. However, this assumption may well misrepresent the true condition of air flow if other psychrometric properties, such as humidity ratio or water vapour pressure, are not kept constant. For this reason, in the present work, the variable dry air mass flow rate is used instead of air velocity to assure that a fixed amount of dry air passes through a thin layer of Brazilian peppertree leaves per unit of time and per unit of gross cross-sectional area of the drying chamber. As a matter of fact, comparison with published results is rendered even more difficult since the gross cross-sectional area of the perforated metal plate supporting the product layer is hardly mentioned.

Tests involved three levels of drying air temperature $\left(35,40\right.$, and $\left.45^{\circ} \mathrm{C}\right)$, one level of dry air mass flow rate $\left(0.731 \pm 0.017 \mathrm{~kg} \mathrm{~s}^{-1} \mathrm{~m}^{-2}\right)$ and were conducted at a mean ambient air humidity ratio of $0.008 \pm 0.001 \mathrm{~kg} \mathrm{~kg}^{-1}$. Three replicates were performed at each drying run. Table 1 summarises the experimental parameters in all cases studied. Moisture equilibria were determined experimentally using the dynamic method by exposing samples of the product to constant environmental conditions in a Binder KBF 720 climatic chamber. Equilibrium moisture tests were carried out at three levels of air temperature $\left(35,40\right.$ and $\left.45^{\circ} \mathrm{C}\right)$ and nine levels of relative humidity $(20,25,30,40,50,60,70,80$ and $90 \%)$. Ten replications for each combination of temperature and relative humidity were conducted and the samples remained in the climatic chamber until weight variation on three successive measurements produced variations on moisture content equal or less than 0.001 decimal d.b. The weight of the sample was monitored at three-day intervals. Detailed experimental procedures to determine the moisture sorption isotherms were found in Spiess and Wolf (1987).

\section{Drying kinetics}

The experimental drying curves were constructed for each sample by plotting the dimensionless moisture ratio (MR) values versus the drying time t. MR is defined as the ratio of free moisture in the product at time $\mathrm{t}$ to total free moisture present at the start of the drying process and was calculated using Eq. (1), where $\mathrm{M}_{\mathrm{t}}$ is the moisture content at any time $\mathrm{t}, \mathrm{M}_{0}$ is the initial 
moisture content and $\mathrm{M}_{\mathrm{e}}$ is the equilibrium moisture content.

$$
\mathrm{MR}=\frac{\mathrm{M}_{\mathrm{t}}-\mathrm{M}_{\mathrm{e}}}{\mathrm{M}_{0}-\mathrm{M}_{\mathrm{e}}}
$$

A better understanding of the factors that affect the rate of moisture loss is given by differentiating the drying curve and plotting the results as a function of time or moisture content. Differentiation gives the drying rate $(\zeta)$ in terms of $\mathrm{kg}$ of water per $\mathrm{kg}$ of dry matter per hour and is defined by Eq. (2):

$$
\zeta=\frac{\partial M}{\partial t}=\lim _{\Delta t \rightarrow 0} \frac{M(t+\Delta t)-M(t)}{\Delta t}
$$

Table 1. Leaf collection time, average drying and plant parameters, total drying time and equilibrium moisture

\begin{tabular}{|c|c|c|c|c|c|c|c|c|c|}
\hline $\begin{array}{l}\text { Test } \\
\text { number }\end{array}$ & 1 & 2 & 3 & 4 & 5 & 6 & 7 & 8 & 9 \\
\hline $\begin{array}{c}\text { Leaf } \\
\text { collection } \\
\text { time }(\mathrm{h})\end{array}$ & 0800 & 0800 & 0800 & 1200 & 1200 & 1200 & 1700 & 1700 & 1700 \\
\hline Ambient air & & & & & & & & & \\
\hline $\begin{array}{c}\text { Temperature, } \\
{ }^{\circ} \mathrm{C}\end{array}$ & 23.6 & 22.7 & 24.8 & 23.2 & 22.7 & 23.7 & 23.5 & 23.1 & 23.6 \\
\hline $\begin{array}{l}\text { Humidity } \\
\text { ratio, } \mathrm{kg} \mathrm{kg}^{-1} \\
\text { Drying air }\end{array}$ & 0.009 & 0.008 & 0.009 & 0.008 & 0.008 & 0.009 & 0.009 & 0.008 & 0.008 \\
\hline $\begin{array}{c}\text { Temperature, } \\
{ }^{\circ} \mathrm{C}\end{array}$ & 35.0 & 40.0 & 44.8 & 35.0 & 40.1 & 45.0 & 35.0 & 40.0 & 45.0 \\
\hline $\begin{array}{l}\text { Dry mass air } \\
\text { flow rate, } \mathrm{kg} \\
\mathrm{s}^{-1} \mathrm{~m}^{-2} \\
\text { Initial plant } \\
\text { parameters }\end{array}$ & 0.758 & 0.724 & 0.719 & 0.755 & 0.717 & 0.722 & 0.744 & 0.722 & 0.716 \\
\hline $\begin{array}{c}\text { Temperature, } \\
{ }^{\circ} \mathrm{C}\end{array}$ & 23.6 & 22.7 & 24.8 & 23.2 & 22.7 & 23.7 & 23.5 & 23.1 & 23.6 \\
\hline $\begin{array}{c}\text { Moisture } \\
\text { content, \% } \\
\text { w.b.* }\end{array}$ & 59.6 & 58.3 & 58.0 & 57.7 & 57.5 & 56.4 & 58.4 & 59.8 & 58.3 \\
\hline $\begin{array}{c}\text { Leaf } \\
\text { thickness, } \\
\text { mm }\end{array}$ & 0.140 & 0.142 & 0.141 & 0.145 & 0.143 & 0.144 & 0.142 & 0.144 & 0.145 \\
\hline $\begin{array}{l}\text { Final plant } \\
\text { parameters }\end{array}$ & & & & & & & & & \\
\hline $\begin{array}{c}\text { Temperature, } \\
{ }^{\circ} \mathrm{C}\end{array}$ & 35.0 & 40.0 & 44.8 & 35.0 & 40.1 & 45.0 & 35.0 & 40.0 & 45.0 \\
\hline $\begin{array}{c}\text { Moisture } \\
\text { ontent, \% w.b. }\end{array}$ & 13.6 & 13.6 & 13.7 & 13.5 & 13.5 & 13.4 & 13.4 & 13.1 & 13.5 \\
\hline $\begin{array}{l}\text { Moisture ratio, } \\
\text { dimensionless }\end{array}$ & 0.19 & 0.21 & 0.22 & 0.20 & 0.21 & 0.23 & 0.19 & 0.20 & 0.22 \\
\hline $\begin{array}{l}\text { Total drying } \\
\text { time, } \mathrm{h}\end{array}$ & 10.5 & 8.0 & 4.0 & 9.0 & 7.0 & 4.0 & 11.0 & 7.5 & 4.5 \\
\hline $\begin{array}{l}\text { Equilibrium } \\
\text { moisture } \\
\text { content \% w.b. }\end{array}$ & 2.5 & 2.0 & 1.5 & 2.5 & 1.5 & 0.8 & 2.8 & 1.5 & 0.5 \\
\hline
\end{tabular}
content of Schinus terebinthifolius Raddi.

Theoretical and semi-empirical mathematical drying models ${ }^{1}$

\footnotetext{
${ }^{1}$ See NOMENCLATURE for the definition of the symbols of variables and the corresponding units
}

The Fick's second law of diffusion was used to describe the movement of moisture by liquid diffusion as the principal mass transfer mechanism during convective drying. Assuming that the medium is isotropic, the diffusion coefficient is 
constant and the volume shrinkage is negligible, Fick's second law in three-dimensional space can be written as:

$\frac{\partial \mathrm{M}}{\partial \mathrm{t}}=\mathrm{D}_{\mathrm{eff}} \nabla^{2} \mathrm{M}$

If $\mathrm{D}_{\text {eff }}$ is assumed to depend on position in the product, or on moisture content or temperature, then Eq. (3) may be replaced by

$\frac{\partial \mathrm{M}}{\partial \mathrm{t}}=\nabla\left[\mathrm{D}_{\mathrm{eff}}(\nabla \mathrm{M})\right]$

In order to solve any model such as those given by Eqs. (3) and (4) an appropriate geometric shape must be assumed for the approximate representation of the individual sample, i.e., slab, cylinder or sphere. In the case of one-dimensional diffusion in a medium bounded by two parallel planes (infinite slab) considered so thin that effectively all the mass transfer occurs through the plane faces and a negligible amount through the edges, Crank (1975) proposed the following solution for Eq. (3), where L represents half thickness of the slab when mass transfer occurs on its both sides.

$\frac{M_{t}-M_{e}}{M_{0}-M_{e}}=\frac{8}{\pi^{2}} \sum_{n=0}^{\infty} \frac{1}{(2 n+1)^{2}} \exp \left[-D_{\text {eff }}(2 n+1)^{2} \pi^{2} \frac{t}{4 L^{2}}\right]$

For long drying times, Eq. (5) simplifies to a limiting form of diffusion equation as follows:

$\frac{\mathrm{M}_{\mathrm{t}}-\mathrm{M}_{\mathrm{e}}}{\mathrm{M}_{0}-\mathrm{M}_{\mathrm{e}}}=\frac{8}{\pi^{2}} \exp \left[-\mathrm{D}_{\mathrm{eff}} \pi^{2} \frac{\mathrm{t}}{4 \mathrm{~L}^{2}}\right]$

Although numerical solutions of differential equations in drying have been proposed for various geometries, semi-theoretical and empirical equations have also been used to predict kinetics in drying of agricultural products as well as to provide subsidies for the development of more efficient and adequate driers for each type of product. In this work, besides the theoretical approach, the experimental data from convective drying were also fitted to the Lewis model. Lewis (1921) proposed a semi-empirical drying model (Eq. 7), analogous to Newton's law of cooling, which postulates that the rate of change in moisture content is proportional to the instantaneous difference between the moisture content of the material (M) and its equilibrium moisture content $\left(\mathrm{M}_{\mathrm{e}}\right)$.
$\frac{\mathrm{dM}}{\mathrm{dt}}=-\mathrm{k}\left(\mathrm{M}-\mathrm{M}_{\mathrm{e}}\right)$

The integrated form of Eq. (7) yields Eq. (8), which mathematically describes the drying curve of a product, i.e., how its moisture ratio decreases as a function of drying time t. Eq. (8) is referred to as the Lewis model, the Newton model, or the exponential or logarithmic model in drying literature.

$\mathrm{MR}=\exp (-\mathrm{kt})$

The activation energy $E_{a}$ was calculated using an Arrhenius-type relationship such as Eq. (9). The activation energy is considered the amount of energy in excess of the average energy level which water molecules must have in order for diffusion to proceed (LIN et al., 1973).

$\ell \mathrm{n}\left(\mathrm{D}_{\mathrm{eff}}\right)=\ell \mathrm{n}\left(\mathrm{D}_{0}\right)-\frac{\mathrm{E}_{\mathrm{a}}}{\mathrm{RT}_{\mathrm{abs}}}$

\section{Data analysis}

The statistical design was completely randomised in a factorial $3 \times 3$ arrangement (temperature $\mathrm{x}$ leaf collection time), with three replicates, which totalled 27 experimental units. Effective moisture diffusivity was estimated using the method of slopes described by Porter et al. (1973). The experimental data for the moisture ratio and drying time variables from convective drying were fitted both to the diffusion model given by Eq. (6), and the Lewis model given by Eq. (8), using the Gauss-Newton procedure implemented over nonlinear regression analysis using the STATISTICA ${ }^{\mathrm{TM}}$ software package. The suitability of the models to describe the phenomenon studied was evaluated through the calculation with the following statistical parameters and according to the following criteria: (1) determination coefficient $r^{2} \geq 95 \%$ (2) root mean square error RMSE $\leq 0.050$ (3) mean absolute percentage error $\eta \leq 10 \%$ (4) mean bias $\xi$ close to zero and (5) fit index $\delta$ close to unity.

Equations (10) to (13) (presented below) were used to calculate RMSE (GUNHAM et al., 2005), $\eta$ (MADAMBA et al., 1996), $\xi$ (GUNHAM et al., 2005) and $\delta$ (WILLMOTT, 1982) where $M_{\text {est }}$ represents the moisture ratio estimated by the model, $\mathrm{MR}_{\text {exp }}$ represents the experimental moisture ratio and $\mathrm{N}$ represents the number of observations during the experiment. In Eq. (13), $\mid \mathrm{MR}_{\mathrm{est}, \mathrm{i}}^{\prime} \mathrm{I}=\mathrm{MR}_{\mathrm{est}, \mathrm{i}}$ - $\overline{\mathrm{MR}}_{\exp }$ and $\mid \mathrm{MR}_{\text {exp }, \mathrm{i}}^{\prime} \mathrm{I}=\mathrm{MR}_{\mathrm{exp}, \mathrm{i}}-\overline{\mathrm{MR}}_{\exp }$. 


$$
\begin{aligned}
& \operatorname{RMSE}=\left[\frac{1}{\mathrm{~N}} \sum_{\mathrm{i}=1}^{\mathrm{N}}\left(\mathrm{MR}_{\mathrm{exp}, \mathrm{i}}-\mathrm{MR}_{\mathrm{est}, \mathrm{i}}\right)^{2}\right]^{1 / 2} \\
& \eta=\frac{100}{N} \sum_{i=1}^{N}\left(\frac{\left|R_{\text {exp,i }}-M_{\text {est }, i}\right|}{M R_{\text {exp }, i}}\right) \\
& \xi=\frac{1}{\mathrm{~N}} \sum_{\mathrm{i}=1}^{\mathrm{N}}\left(\mathrm{MR}_{\mathrm{est}, \mathrm{i}}-\mathrm{MR}_{\mathrm{exp}, \mathrm{i}}\right) \\
& \delta=1-\left[\frac{\sum_{i=1}^{N}\left(M_{\text {est,i }}-M_{\text {exp,i }}\right)^{2}}{\sum_{i=1}^{N}\left(M R_{\text {est,i }}^{\prime}|+| M R_{\text {exp }, \mathrm{i}}^{\prime}\right)^{2}}\right], 0 \leq \delta \leq 1
\end{aligned}
$$

\section{RESULTS AND DISCUSSION}

The study consisted of two stages, the first of which was designed to assess the effect of temperature and leaf collection time on the thinlayer drying kinetics of Brazilian peppertree leaves. The second stage of analysis was employed to verify whether the diffusion and Lewis models can be considered applicable to describe the experimental drying curves of the product under the examined conditions.

\section{Effect of air temperature and leaf collection time}

The effect of the drying-air temperature on the reduction of moisture ratio as a function of time, for a dry air mass flow rate of $0.731 \pm 0.018 \mathrm{~kg} \mathrm{~s}^{-1}$ $\mathrm{m}^{-2}$, humidity ratio of $0.008 \pm 0.001 \mathrm{~kg} \mathrm{~kg}^{-1}$, $58.2 \pm 1.0 \%$ w.b. $(\mathrm{MR}=1.00)$ and $13.5 \pm 0.2 \%$ w.b. $(\mathrm{MR}=0.20)$ initial and final moisture contents and moisture ratios, respectively, at three different leaf collection times, is shown in Figure 3. The results show that the rate of reduction in moisture content increases considerably with rising air temperatures. For leaves collected at $0800 \mathrm{~h}$ (Figure 3A), the drying time to reach an MR of 0.22 for $35^{\circ} \mathrm{C}$ was 10 $\mathrm{h}$, while $45^{\circ} \mathrm{C}$ required $3.5 \mathrm{~h}$, i.e., drying time was reduced to almost two-thirds with a $10^{\circ} \mathrm{C}$ increase in temperature. Similar effects were observed when leaves were collected at $1200 \mathrm{~h}$ and $1700 \mathrm{~h}$. This behaviour is in accordance with reported findings in the literature for the drying of some medicinal and aromatic plants: Phyllanthus amarus and Phyllanthus niruri (SOUSA et al., 2018), Bauhinia forficata (SILVA et al., 2017), thyme (RODRÍGUEZ et al., 2014; LAHNINE et al., 2016), peppermint (OZGUVEN et al., 2016), Stevia rebaudiana (LEMUS-MONDACA et al., 2015), lemon-scented grass (OLIVEIRA et al., 2011), black tea (TEMPLE; van BOXTEL, 1999), mint (LEBERT et al., 1992; ERTEKIN; HEYBELI, 2014), Taxus clippings (HANSEN et al., 1993), roots of purple coneflower (KABGANIAN et al., 2002), bay leaves (DEMIR et al., 2004), and dill and parsley leaves (DOYMAZ et al., 2006).

Goneli et al. (2014) dried Brazilian peppertree leaves in a forced ventilation oven at $40^{\circ} \mathrm{C}$ and the time to reach the same final MR was $11 \mathrm{~h}$, whereas in our work the corresponding drying time was $7-8 \mathrm{~h}$. This discrepancy may be attributed to differences in dry air mass flow rates and possibly by leaf spatial distribution pattern inside the drying trays. In our work, leaves were placed tangentially to airflow direction (Figure 1), a distribution that may have lead to reductions in resistance to airflow, thus increasing drying rates. The fact that pressure drop is a function of flow direction means that leaves, as placed in drying and storage structures, are anisotropic materials. This has important implications in agricultural products drier design and in analyses of systems wherein the airflow is non linear (BROOKER et al., 1992). The only recognisable effect of leaf collection time on the reduction of moisture ratio as a function of time occurred for $35^{\circ} \mathrm{C}$ as shown in Figure 4. Ambient air conditions have a more pronounced effect on low rather than on high temperature drying. Low temperature drying usually refers to drying that uses air that is either unheated or heated to raise its temperature $6^{\circ} \mathrm{C}$ or less. The results obtained here showed that the rate of reduction in moisture ratio was higher for leaves collected at $1200 \mathrm{~h}$, when the relative humidity, humidity ratio and enthalpy of both ambient air $\left(46 \%, 0.008 \mathrm{~kg} \mathrm{~kg}^{-1}\right.$, and $45 \mathrm{~kJ}$ $\left.\mathrm{kg}^{-1}\right)$ and drying air $\left(25 \%, 0.008 \mathrm{~kg} \mathrm{~kg}^{-1}\right.$, and $58 \mathrm{~kJ}$ $\mathrm{kg}^{-1}$ ) promote a faster drying than the psychrometric conditions observed at $0800 \mathrm{~h}$ and $1700 \mathrm{~h}$, i.e., $49 \%$, $0.009 \mathrm{~kg} \mathrm{~kg}^{-1}$ and $47 \mathrm{~kJ} \mathrm{~kg}^{-1}$ (ambient air) and 27\%, $0.009 \mathrm{~kg} \mathrm{~kg}^{-1}$ and $56 \mathrm{~kJ} \mathrm{~kg}^{-1}$ (drying air), respectively.

Although the drying curves shown in Figure 3 may indicate that the reduction in moisture is subject to variation with elapsed time, it does not give insights into the rate of moisture loss (Eq. 2). Data expressing the effect of temperature on the drying rate as the drying progresses, for leaves collected at $1700 \mathrm{~h}$, is shown in Figure 5 for a dry air mass flow rate of $0.727 \pm 0.015 \mathrm{~kg} \mathrm{~s}^{-1} \mathrm{~m}^{-2}$ and humidity ratio of $0.008 \pm 0.001 \mathrm{~kg} \mathrm{~kg}^{-1}$. For purposes of clarity, the graph showing the variation of the drying rate at the earlier stages of drying is shown as an insert in Figure 5. These profiles exhibit only falling-rate periods from the start of data collection 
(i.e. $\mathrm{t} \geq 0.083 \mathrm{~h}$ ), although the curves approach asymptotic values towards the end of the drying process. The absence of a constant-rate drying period is in accordance with published results related to herbs, aromatic and medicinal plants: peppermint (ARSLAN et al., 2010), lemon-scented grass (OLIVEIRA et al., 2011), black tea (PANCHARIYA et al., 2002), mint leaves (DOYMAZ, 2006), parsley and basil (AKPINAR, 2006) and betel leaves (PIN et al., 2009).

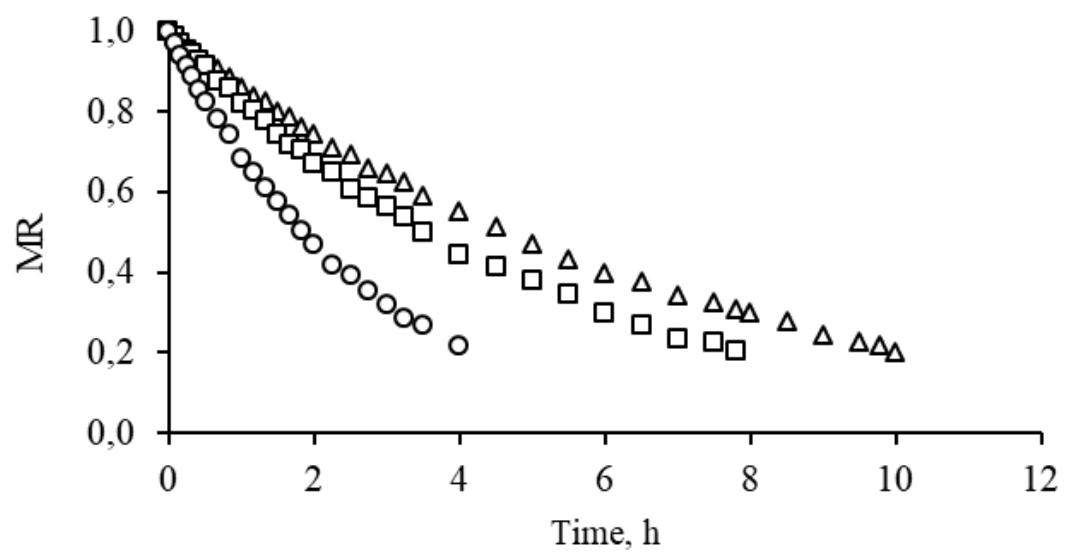

A

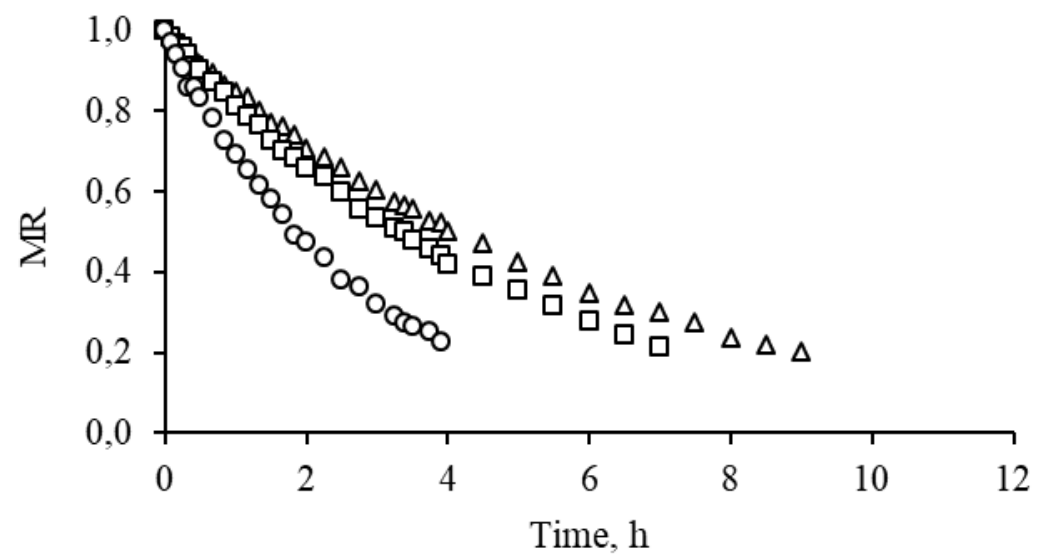

B

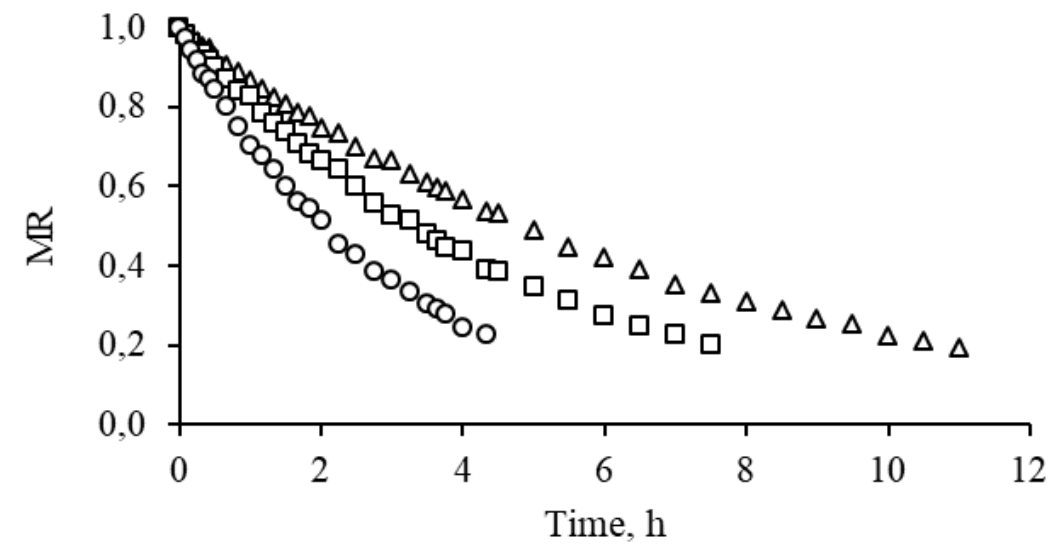

C

Figure 3. Experimental drying curves for samples of Brazilian peppertree leaves in a single layer with a dry air mass flow rate of $0.731 \mathrm{~kg} \mathrm{~s}^{-1} \mathrm{~m}^{-2}$, humidity ratio of $0.008 \mathrm{~kg} \mathrm{~kg}^{-1}$, for leaves collected at $0800 \mathrm{~h}$ (A), $1200 \mathrm{~h}(\mathrm{~B})$, and $1700 \mathrm{~h}(\mathrm{C})$, at indicated values of temperature. $\triangle, 35^{\circ} \mathrm{C} ; \square, 40^{\circ} \mathrm{C} ; \mathrm{O}, 45^{\circ} \mathrm{C}$. 


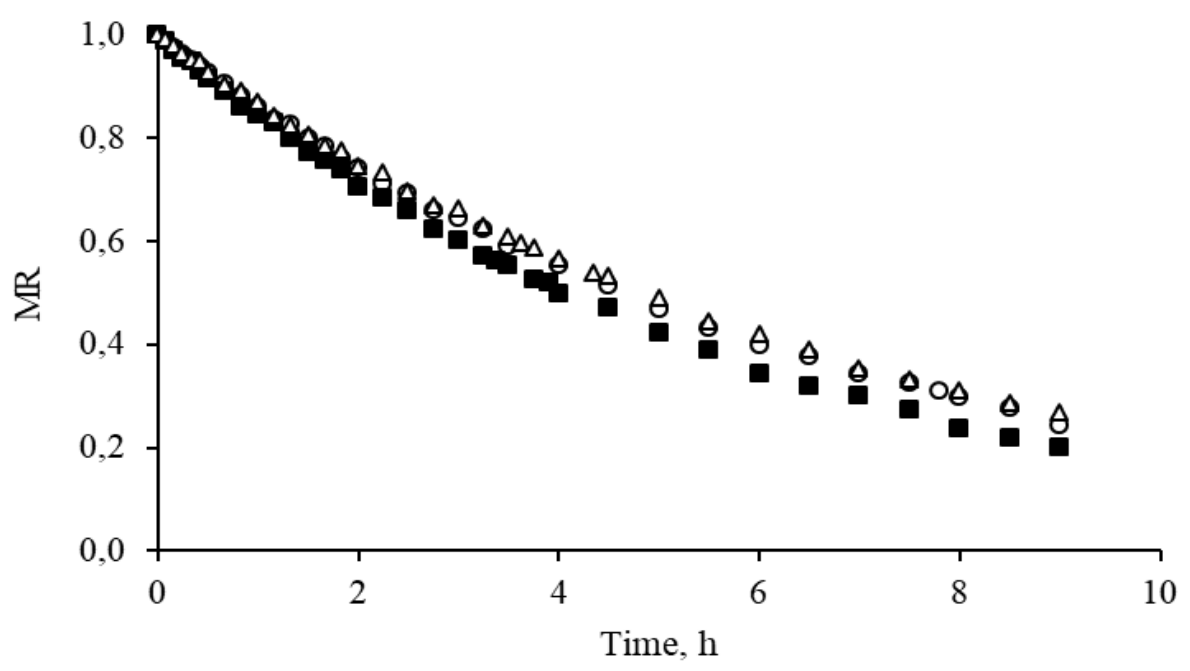

Figure 4. Experimental drying curves for samples of Brazilian peppertree leaves in a single layer, at $35^{\circ} \mathrm{C}$, with a dry air mass flow rate of $0.752 \mathrm{~kg} \mathrm{~s}^{-1} \mathrm{~m}^{-2}$, humidity ratio of $0.009 \mathrm{~kg} \mathrm{~kg}^{-1}$, at indicated leaf collection times. $\mathrm{O}, 0800 \mathrm{~h} ; \mathbf{\square}, 1200 \mathrm{~h} ; \triangle, 1700 \mathrm{~h}$.

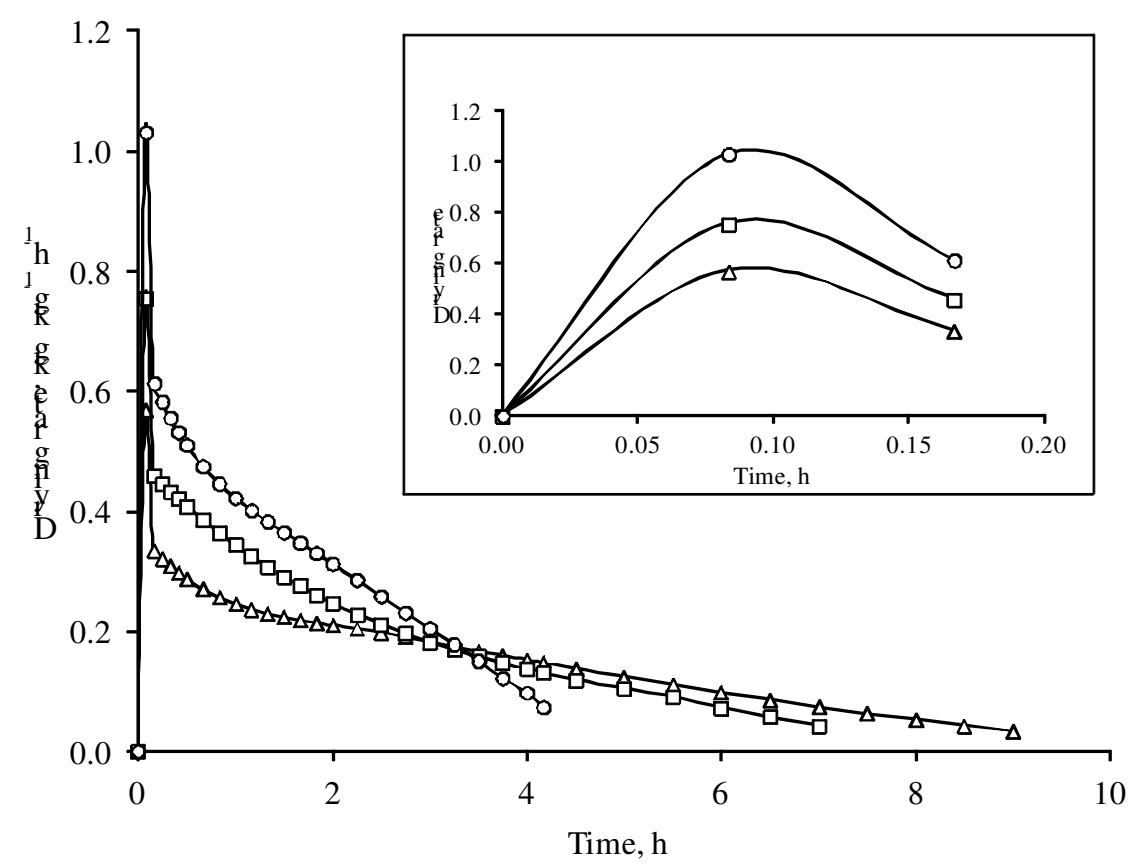

Figure 5. Drying rate as a function of time for samples of Brazilian peppertree leaves in a thin layer with a dry air mass flow rate of $0.727 \mathrm{~kg} \mathrm{~s}^{-1} \mathrm{~m}^{-2}$, humidity ratio of $0.008 \pm 0.001 \mathrm{~kg} \mathrm{~kg}^{-1}$, for leaves collected at $1700 \mathrm{~h}$, and indicated values of temperature. $\triangle, 35^{\circ} \mathrm{C} ; \square, 40^{\circ} \mathrm{C} ; \mathrm{O}, 45^{\circ} \mathrm{C}$. Insert shows the reduction of the drying rate $\left(\mathrm{kg} \mathrm{kg}^{-1} \mathrm{~h}^{-1}\right)$ during the first 10 min of drying.

It may be noted that during the first 3.25 hours of the drying process, the drying rate at $45^{\circ} \mathrm{C}$ is higher than the values observed at $35^{\circ} \mathrm{C}$ and $40^{\circ} \mathrm{C}$. However, as the drying continues towards the equilibrium moisture content, the $40^{\circ} \mathrm{C}$ and $45^{\circ} \mathrm{C}$ curves fall below the $30^{\circ} \mathrm{C}$, indicating a possible change in the mechanisms governing the internal moisture movement. In any case, at the end of the first 3.25 hours drying period, the moisture content of the product dried at $45^{\circ} \mathrm{C}$ had been brought down to $20 \%$ w.b. $(\mathrm{MR}=0.33)$, whereas the samples dried at $40^{\circ} \mathrm{C}$ and $35^{\circ} \mathrm{C}$ had reached $31 \%$ w.b. (MR $=0.51)$ and $38 \%$ w.b. $(\mathrm{MR}=0.63)$, respectively. After this 3.25 -hour period, the product drying at $35^{\circ} \mathrm{C}$ has a higher moisture content value, i.e., it has a greater amount of free water to produce a higher drying rate as compared to the product drying at higher temperatures. As the humidity ratio and the 
dry air mass flow rate remained fairly constant, it is assumed that external conditions did not affect the convective mass coefficient. Belghit et al. (2000) observed a decrease in the drying rate of verbena as the temperature increased from $30^{\circ} \mathrm{C}$ to $50^{\circ} \mathrm{C}$, for an air velocity of $2.6 \mathrm{~m} \mathrm{~s}^{-1}$. As an explanation to this anomalous behaviour, they suggested that the drying was not controlled by the temperature alone, but rather by an appreciable diffusional resistance which could be sensitive to the drying air velocity. The results obtained by Doymaz et al (2006) also clearly show that the drying rates of dill and parsley leaves at $70^{\circ} \mathrm{C}$ are higher than the drying rates at $50^{\circ} \mathrm{C}$ and $60^{\circ} \mathrm{C}$ only in the first third of the drying process. However, higher drying rates associated with higher drying temperatures at the initial stages of the drying of herbs were not observed by other authors (LEBERT et al., 1992; KAYA; AYDIN, 2009).

Figure 6 shows the variation of the drying rate of Brazilian peppertree leaves as a function of moisture ratio, for leaves collected at $1700 \mathrm{~h}$, for a dry air mass flow rate of $0.727 \pm 0.015 \mathrm{~kg} \mathrm{~s}^{-1} \mathrm{~m}^{-2}$ and humidity ratio of $0.008 \pm 0.001 \mathrm{~kg} \mathrm{~kg}^{-1}$, at indicated values of temperature.

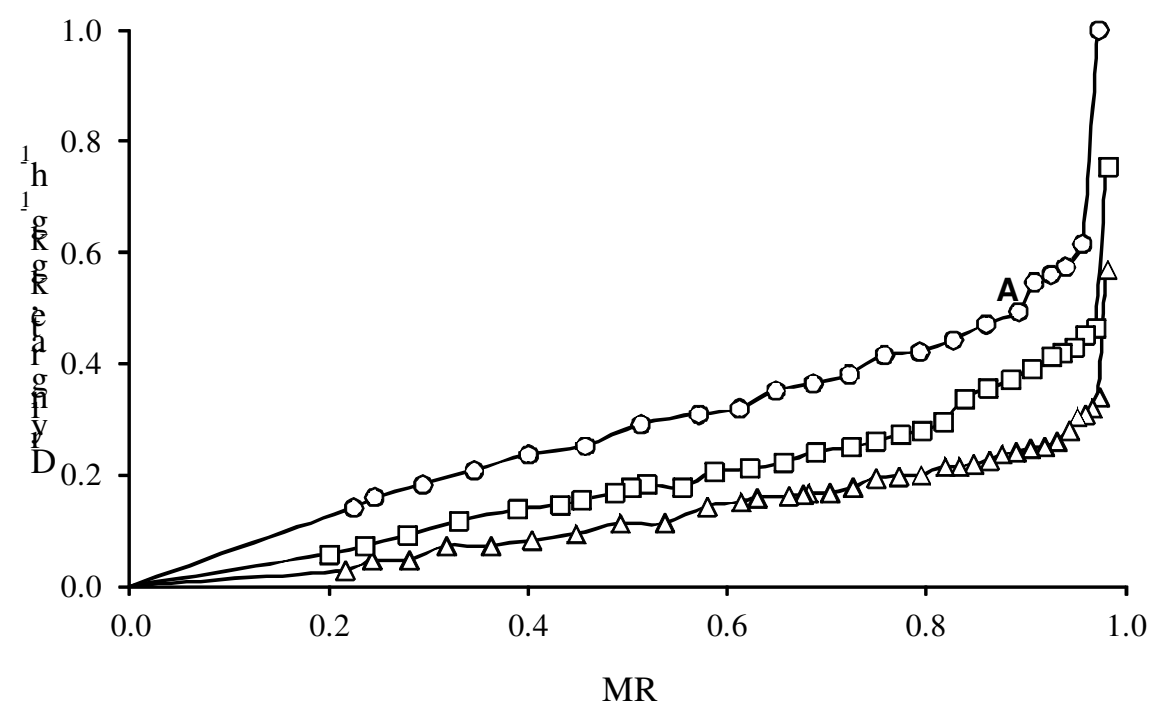

Figure 6. Drying rate as a function of the moisture ratio for samples of Brazilian peppertree leaves in a thin layer with a dry air mass flow rate of $0.727 \mathrm{~kg} \mathrm{~s}^{-1} \mathrm{~m}^{-2}$, humidity ratio of $0.008 \pm 0.001 \mathrm{~kg} \mathrm{~kg}^{-1}$, for leaves collected at $1700 \mathrm{~h}$, and indicated values of temperature. $\triangle, 35^{\circ} \mathrm{C} ; \square, 40^{\circ} \mathrm{C} ; \mathrm{O}, 45^{\circ} \mathrm{C}$.

For the same value of MR, higher drying rates were obtained at higher drying-air temperatures. Although Figure 6 shows another example of how temperature influences drying rate, it does not reveal the details shown in Figure 5 because the achievement of the same value of MR occurs at different drying times. The rate curves in Figure 6 show that the drying process is not a smooth, continuous one, as Figure 3 might suggest, in which a single mechanism controls throughout, mainly at higher temperatures. According to Porter et al. (1973), a point of inflexion in these curves (as point $\mathrm{A}$ on the $45^{\circ} \mathrm{C}$ curve) represents the point at which all the exposed surface of the product becomes completely unsaturated and marks the start of that portion of the drying cycle during which the rate of internal moisture movement controls the drying rate. A similar trend of the rate curves against moisture ratio was observed for leaves collected at $0800 \mathrm{~h}$ and $1200 \mathrm{~h}$, having a point of inflexion $\mathrm{A}$ at $\mathrm{MR}=0.9$ and $\zeta=0.50 \mathrm{~kg} \mathrm{~kg}^{-1} \mathrm{~h}^{-1}$. This behaviour is another indication that leaf collection time has little influence on the drying kinetics of Brazilian peppertree leaves.

Doymaz (2006) obtained points of inflexion at the onset of the drying of mint leaves in curves representing the variation of the drying rate as a function of moisture ratio. Nonetheless, it was argued that the shape of the curves demonstrated the existence of a smooth diffusion mechanism controlling the drying behaviour. Pin et al. (2009) studied the effect of drying air temperature on the drying kinetics of betel leaves and observed points of inflexion in the $\zeta v s$ MR curves only at higher temperatures $\left(50,60\right.$ and $70^{\circ} \mathrm{C}$ ) and short constantrate periods were also noticed in the middle of the drying process. This behaviour prompted the authors to suggest that the drying process was 
controlled by the internal diffusion of moisture within the product. However, no point of inflexion or a constant-rate period was observed at $40^{\circ} \mathrm{C}$; at this latter temperature $\zeta$ varied linearly with MR.

\section{Effective moisture diffusivity and activation energy}

Figure 7 shows the experimental and estimated natural logarithmic moisture ratio as a function of drying time for samples of Brazilian peppertree leaves collected at $0800 \mathrm{~h}$ for different drying-air temperatures. The straight lines obtained, all with coefficients of determination close to unity, confirm that moisture moves by diffusion within the leaves and that the slopes of the lines equal $D_{\text {eff }} \pi^{2} / 4$ $\mathrm{L}^{2}$ (PORTER et al., 1973). Leaf thickness varied from 0.140 to $0.145 \mathrm{~mm}$ (Table 1) and effective diffusivities $\left(\mathrm{D}_{\text {eff }}\right)$ are listed in Table 2. $\mathrm{D}_{\text {eff }}$ was found to increase with temperature at each leaf collection time. Higher values of $D_{\text {eff }}$ associated with higher drying-air temperatures have been also observed for lemon-scented grass (OLIVEIRA et al., 2011), black tea (PANCHARIYA et al., 2002), dill and parsley leaves (DOYMAZ et al., 2006) and coriander leaves and stems (SILVA et al., 2008). $D_{\text {eff }}$ values listed in Table 2 corroborate the behaviour shown in Figures 3 and 4, for leaves dried at $35^{\circ} \mathrm{C}$, with regard to a more intense drying pattern for leaves collected at $1200 \mathrm{~h}$. Values of $D_{\text {eff }}$ at $40^{\circ} \mathrm{C}$ reported herein are lower than that obtained by Goneli et al. (2014), i.e., $1.48 \times 10^{-12} \mathrm{~m}^{2} \mathrm{~s}^{-1}$, mainly due to differences in leaf thickness.

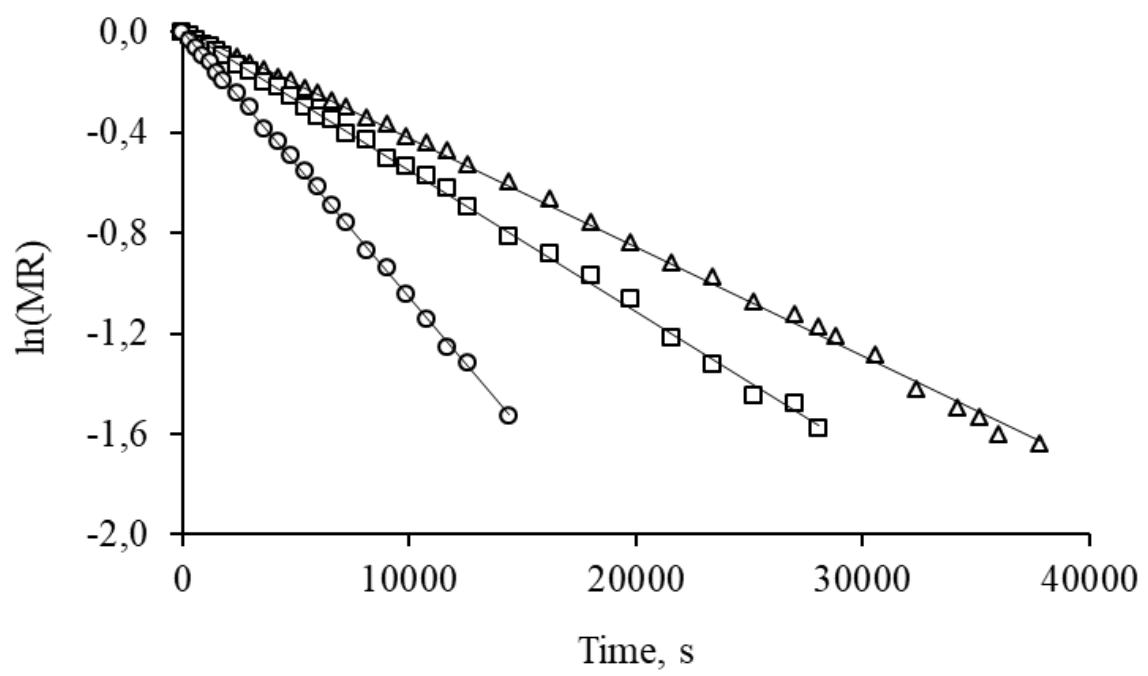

Figure 7. Experimental and estimated natural logarithmic moisture ratio as a function of drying time for samples of Brazilian peppertree leaves in a thin layer with a dry air mass flow rate of $0.727 \mathrm{~kg} \mathrm{~s}^{-1}$ $\mathrm{m}^{-2}$, humidity ratio of $0.008 \pm 0.001 \mathrm{~kg} \mathrm{~kg}^{-1}$, for leaves collected at $0800 \mathrm{~h}$, and indicated values of temperature. $\triangle, 35^{\circ} \mathrm{C} ; \square, 40^{\circ} \mathrm{C} ; \mathrm{O}, 45^{\circ} \mathrm{C}$.

Table 2: Effective diffusivity during drying of Brazilian peppertree leaves

\begin{tabular}{cccc}
\hline Drying-air temperature $\left({ }^{\circ} \mathrm{C}\right)$ & \multicolumn{3}{c}{ Leaf collection time $(\mathrm{h})$} \\
\cline { 2 - 4 } & 0800 & \multicolumn{3}{c}{1200} & 1700 \\
\cline { 2 - 4 } & 3.18 & Effective diffusivity $\left(\mathrm{m}^{2} \mathrm{~s}^{-1} \times 10^{-13}\right)$ \\
\hline 35 & 4.90 & 4.26 & 3.27 \\
40 & 8.06 & 4.97 & 5.04 \\
45 & \multicolumn{3}{c}{8.40} \\
\hline
\end{tabular}

By plotting Eq. (9) as in Fig. 8, the value of $\mathrm{E}_{\mathrm{a}}$ is calculated from the slope of the straight line. The activation energies calculated from the linear regressions, all with coefficients of determination close to unity, were $75.82,55.21$, and $78.05 \mathrm{~kJ} \mathrm{~mol}^{-1}$ for leaves collected at $0800 \mathrm{~h}, 1200 \mathrm{~h}$, and $1700 \mathrm{~h}$, respectively. As $E_{a}$ is temperature-independent in the moderate temperature range usually encountered in agricultural products drying, the values for this present study compare well with that obtained by Goneli et al. (2014), i.e., $74.96 \mathrm{~kJ} \mathrm{~mol}^{-1}$, for leaves of the same species. As deviation from linearity in plots such as that shown in Figure 8 frequently implies that mass transfer is a complex mechanism (LIN et al., 1973), one which involves water and vapour diffusions, Knudsen diffusion, internal evaporation and condensation effects, capillary and hydrodynamic flows (BRUIN; LUYBEN, 1980), it 
is reasonable to expect that transport of water within Brazilian peppertree leaves takes place mainly by diffusion mechanisms. The coefficients of determination for the relationship described by Eq. (9) were $0.9977,0.9046$, and 0.9959 for leaves collected at $0800 \mathrm{~h}, 1200 \mathrm{~h}$, and $1700 \mathrm{~h}$, respectively. The diffusivity constant $D_{0}$ is equivalent to the diffusivity at infinitely high temperature (PANCHARIYA et al., 2002) and its value for leaves dried at $1200 \mathrm{~h}$ was $9.13 \times 10^{-4} \mathrm{~m}^{2}$ $\mathrm{s}^{-1}$.

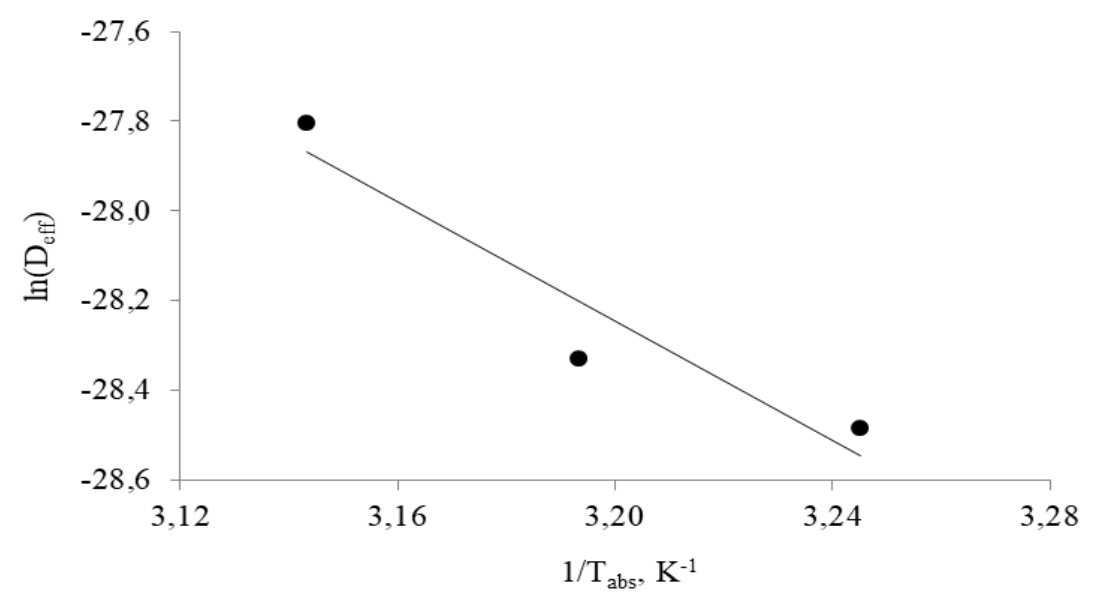

Figure 8. Experimental $(\bullet)$ and estimated $(-)$ natural logarithmic effective diffusivity as a function of the reciprocal of absolute drying temperature for samples of Brazilian peppertree leaves in a thin layer with a dry air mass flow rate of $0.727 \pm 0.015 \mathrm{~kg} \mathrm{~s}^{-1} \mathrm{~m}^{-2}$, humidity ratio of $0.008 \pm 0.001 \mathrm{~kg} \mathrm{~kg}^{-1}$, for leaves collected at $1200 \mathrm{~h}$

\section{Mathematical modelling of the drying curves}

Table 3 shows the resulting drying constant $\mathrm{k}$ of the Lewis model and the statistical parameter values $\left(\mathrm{r}^{2}, \mathrm{RMSE}, \eta, \xi\right.$ and $\delta$ ) used to evaluate the degree of suitability of both the diffusion and Lewis models to the experimental data of convection drying of Brazilian peppertree leaves at 35, 40, and $45^{\circ} \mathrm{C}$, and with $0.731 \pm 0.017 \mathrm{~kg} \mathrm{~s}^{-1} \mathrm{~m}^{-2}$ dry air mass flow rate.

Considering only the coefficient of determination $r^{2}$ as a parameter for assessing goodness of fit, it can be seen that both models fit the drying experimental data according to the established criteria, with values of $r^{2} \geq 0.95$ for all drying conditions. Some authors consider that mathematical drying models with coefficients of determination $\mathrm{r}^{2}>0.93$ may be considered acceptable in the description of the drying process (MADAMBA et al., 1996; PANCHARIYA et al., 2002), although Zanoelo et al. (2006) regarded as accurate a model with $r^{2}<0.90$ in the description of mate leaves drying. However, most studies on the drying of agricultural products report coefficients of determination $\mathrm{r}^{2}>0.98$ for the best drying models (GUNHAN et al., 2005; DOYMAZ et al., 2006; SACILIK; UNAL, 2005; SILVA et al., 2008; GOYAL et al., 2006; OLIVEIRA et al., 2013). However, as demonstrated by Willmott (1982), the exclusive use of $r^{2}$ as the only parameter for evaluating mathematical models is an insufficient and often misleading measure of accuracy.

Most RMSE values obtained with the diffusion model do not satisfy our selection criteria, i.e., RMSE $<0.050$, although the range of variation obtained $0.026 \leq$ RMSE $\leq 0.092$ compares well with published data on model accuracy evaluation (DEMIR et al., 2004, DOYMAZ, 2006; SILVA et al, 2008; TOĞRUL; PEHLIVAN, 2003). In fact, the mean RMSE obtained with the Lewis model, 0.007, is about seven times lower than the value obtained with the diffusion model, 0.052 , which indicates that this latter model may be considered a good predictor of the thin-layer drying behaviour of Brazilian peppertree leaves. Some values obtained with the diffusion model for the mean absolute percentage error do not satisfy our selection criteria, i.e., $\eta \leq$ $10 \%$, but are not sufficiently high enough to disqualify the curves obtained by this model as a good approximation of the experimental data. However, the range of variation obtained with the Lewis model, $0.72 \% \leq \eta \leq 1.48 \%$, undoubtedly indicates this model as a better predictor of the experimental drying curves. The range of variation obtained for the mean absolute percentage error $\eta$ in the present work is narrower to those reported in the literature by researchers in search of a best thinlayer drying model to explain the drying behaviour of a number of agricultural products 
(MADHIYANON et al., 2009; MARTINAZZO et al. 2010; CHENARBON et al., 2011; RADUNZ et al., 2014).

Table 3. Drying rate constant $(\mathrm{k})$ and values of error parameters $\left(\mathrm{r}^{2}, \mathrm{RMSE}, \eta, \xi\right.$ and $\left.\delta\right)$ used to investigate the goodness-of-fit of the diffusion and Lewis mathematical drying models in the description of convective drying at 35,40 , and $45^{\circ} \mathrm{C}$, and with $0.731 \pm 0.017 \mathrm{~kg} \mathrm{~s}^{-1} \mathrm{~m}^{-2}$ dry air mass flow rate

\begin{tabular}{|c|c|c|c|c|c|c|c|c|}
\hline Model & $\begin{array}{c}\text { Tem } \\
\mathrm{p} \\
\left({ }^{\circ} \mathrm{C}\right)\end{array}$ & $\begin{array}{c}\text { Leaf } \\
\text { collection } \\
\text { time (h) }\end{array}$ & $\mathrm{k}$ & $\mathrm{r}^{2}$ & RMSE & $\eta$ & $\xi$ & $\delta$ \\
\hline \multirow[t]{9}{*}{ Diffusion } & \multirow[t]{3}{*}{35} & 0800 & - & 0.95 & 0.026 & 5.59 & 0.002 & 0.997 \\
\hline & & 1200 & - & 0.96 & 0.044 & 8.03 & -0.005 & 0.990 \\
\hline & & 1700 & - & 0.96 & 0.056 & 9.49 & -0.017 & 0.996 \\
\hline & \multirow[t]{3}{*}{40} & 0800 & - & 0.98 & 0.092 & 6.99 & -0.013 & 0.985 \\
\hline & & 1200 & - & 0.96 & 0.045 & 7.88 & -0.006 & 0.989 \\
\hline & & 1700 & - & 0.96 & 0.052 & 8.12 & -0.024 & 0.986 \\
\hline & \multirow[t]{3}{*}{45} & 0800 & - & 0.97 & 0.052 & 10.44 & 0.012 & 0.986 \\
\hline & & 1200 & - & 0.97 & 0.054 & 10.14 & -0.002 & 0.996 \\
\hline & & 1700 & - & 0.96 & 0.049 & 7.38 & -0.024 & 0.996 \\
\hline \multirow[t]{9}{*}{ Lewis } & \multirow[t]{3}{*}{35} & 0800 & 0.1558 & 0.99 & 0.006 & 1.37 & -0.006 & 0.999 \\
\hline & & 1200 & 0.1773 & 0.99 & 0.004 & 0.72 & -0.003 & 0.999 \\
\hline & & 1700 & 0.1486 & 0.99 & 0.009 & 1.21 & -0.005 & 0.999 \\
\hline & \multirow[t]{3}{*}{40} & 0800 & 0.2016 & 0.98 & 0.009 & 1.38 & -0.010 & 0.999 \\
\hline & & 1200 & 0.2151 & 0.99 & 0.009 & 1.20 & -0.010 & 0.999 \\
\hline & & 1700 & 0.2146 & 0.98 & 0.009 & 1.14 & -0.010 & 0.999 \\
\hline & \multirow[t]{3}{*}{45} & 0800 & 0.3821 & 0.99 & 0.004 & 0.77 & 0.003 & 0.999 \\
\hline & & 1200 & 0.3780 & 0.99 & 0.008 & 1.29 & 0.000 & 0.999 \\
\hline & & 1700 & 0.3437 & 0.99 & 0.008 & 1.48 & -0.006 & 0.999 \\
\hline
\end{tabular}

According to Gunhan et al. (2005), the most accurate model is one that has a mean bias $\xi$ close to zero. The range of values of $\xi$ obtained here, -0.024 $\leq \xi_{\text {Diff }} \leq 0.012$ and $0.003 \leq \xi_{\text {Lewis }} \leq 0.010$ also allows us to consider that the Lewis model describes the drying of Brazilian peppertree leaves with greater level of accuracy as compared to the diffusion model. Best-fit models chosen to describe the drying behaviour of agricultural products (KADAM et al., 2011; SAKKALKAR et al., 2013) exhibit $\xi$ ranges similar to the one obtained in the present work with the Lewis model. The results obtained so far concerning the statistical parameters used to evaluate the most accurate drying model were corroborated by the values of the fit index obtained with the Lewis model. Previous works have demonstrated the usefulness of the Lewis model in the description of the thin-layer drying of many agricultural products (BUSER et al., 1999; TEMPLE; van BOXTEL, 1999; ZANOELO et al., 2006; DOYMAZ, 2009; OMID et al., 2009; THERDTHAI; ZHOU, 2009; MOTA et al., 2010). Compared to the Lewis model, the simulation provided by the theoretical diffusion model (Eq. 6) was unsatisfactory as indicated by the values of all statistical parameters. These results indicate that the diffusion model cannot be considered a good predictor of the thin-layer drying behaviour of Brazilian peppertree leaves. Explanations for this behaviour results from misleading assumptions made in the use of the analytical solution of second Fick's law, Eq. (5), which was obtained by considering constant slab thickness, uniform initial moisture distribution within the leaves, assumption that the surface is at its equilibrium moisture content and neglection of temperature gradients in the sample. From the results presented in Table 3, it can be argued that none of these assumptions were fully attained. Besides, it remains to be verified if the difference between the one-term solution of Eq. (6) is significantly different of the series solution of Eq. (5) with higher order terms, although there are evidences that this difference is less than $5 \%$ for long drying times (BROOKER et al., 1992). Fortes and Okos (1980) arrived at the conclusion that even when one accepts the fact that diffusion equations can fit experimental values for some solids, there remains the problem of their physical validity for it 
has been furnishing wrong predictions and misinterpretation of experimental results. They even state that the probable reason for its acceptance is the logarithmic behaviour of the solution of the diffusion equations, resembling experimental drying curves.

Figure 9 shows the experimental data and the drying curve obtained by the Lewis model for Brazilian peppertree leaves at $35^{\circ} \mathrm{C}$ for leaves collected at $0800 \mathrm{~h}$. Similar performances of the model were observed for all other treatments. However, drying models can only be considered satisfactory if, in the description of the experimental drying curves, the residues obtained are solely due to random errors of measurement of the variables involved. If any functional relationship is observed between residues and estimated values of the moisture ratio or the drying time, it can be inferred that the model is inappropriate, indicating that the parameters employed in its development are insufficient to explain the variation of experimental data (BYLER et al., 1987; MOURA et al., 2013). In all cases the residues were randomly above and below zero, denoting that there were no functional relationships between the residues and predicted moistures. This result indicates that there was no interference by non-defined variables in the measured values of moisture ratio. The dispersion of the residues as a function of predicted moisture ratio is shown in Figure 10 for leaves collected at $1200 \mathrm{~h}$ and dried at $45^{\circ} \mathrm{C}$. In all cases the residues were randomly above and below zero, denoting that there are no functional relationships between the residues and predicted moisture ratios. This result indicates that there was no interference by non-defined variables in the measured values of moisture ratio.

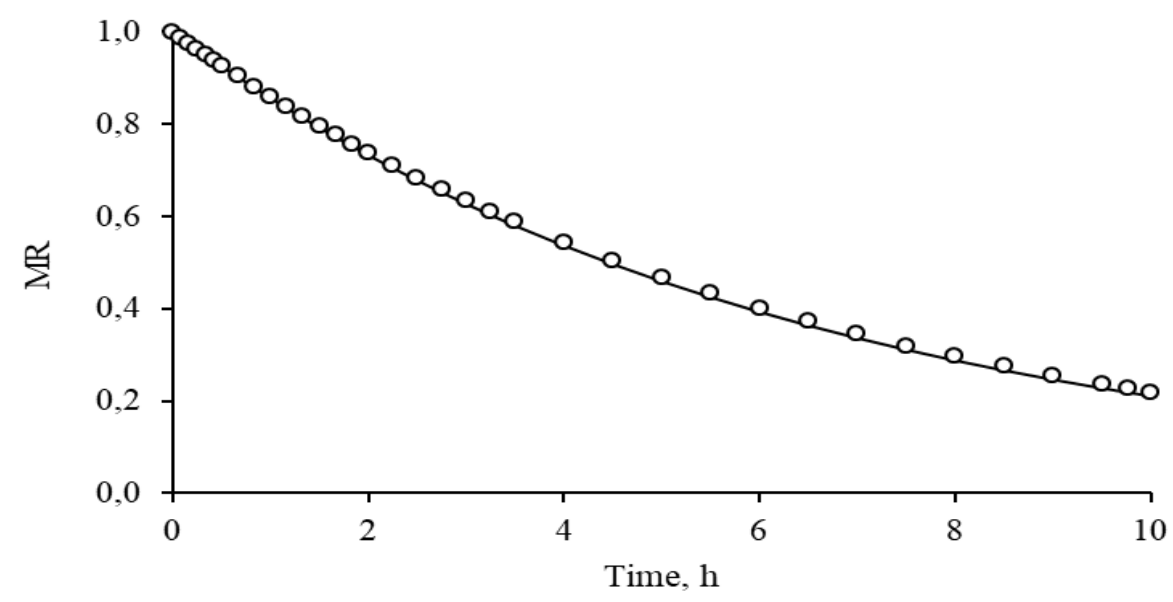

Figure 9. Moisture ratio vs. time (experimental values and drying curve predicted by the Lewis model) for convective drying of Brazilian peppertree leaves at $35^{\circ} \mathrm{C}$ with a dry air mass flow rate of $0.758 \mathrm{~kg} \mathrm{~s}$ ${ }^{1} \mathrm{~m}^{-2}$, humidity ratio of $0.009 \mathrm{~kg} \mathrm{~kg}^{-1}$, for leaves collected at $0800 \mathrm{~h}$.

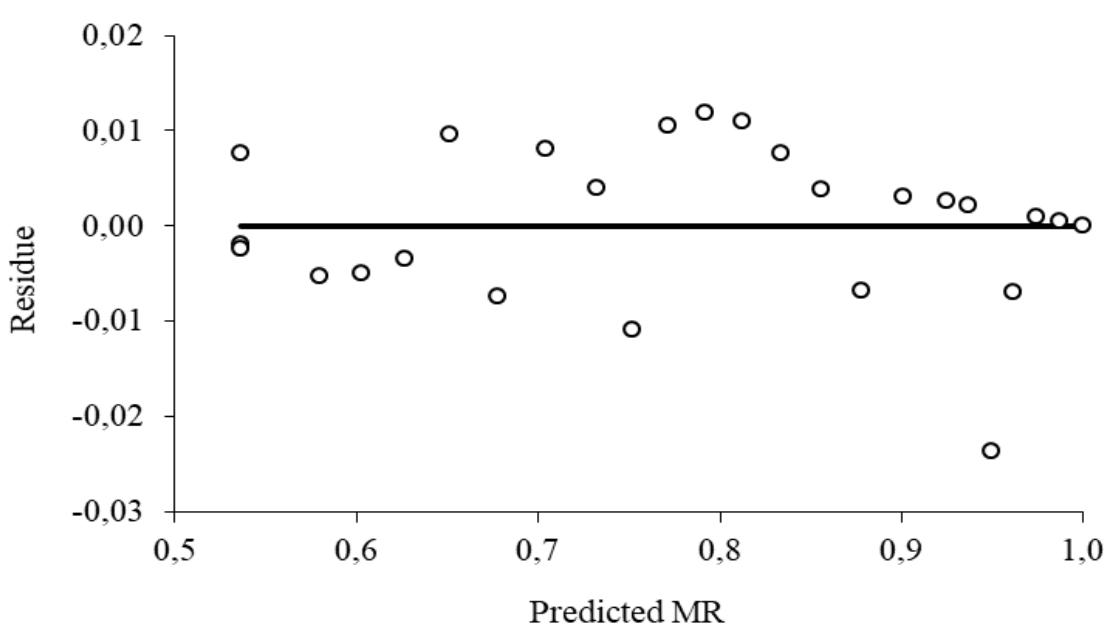

Figure 10. Plot of residuals as a function of moisture ratio predicted by the Lewis model for convective drying, at $45^{\circ} \mathrm{C}$, of Brazilian peppertree leaves collected at $1200 \mathrm{~h}$. 


\section{CONCLUSIONS}

Drying-air temperature had a pronounced effect on mass transfer during convective drying of Brazilian peppertree leaves and drying occurred mainly in the falling rate period.

Leaf collection time had little influence on the drying kinetics.

Effective moisture diffusivity was found to increase with temperature.

The results indicated that the Lewis model was considered a better predictor of the thin-layer drying behaviour of Brazilian peppertree leaves than the theoretical model based on Fick's second law of diffusion.

\section{ACKNOWLEDGEMENTS}

This research work has been sponsored by The Rio de Janeiro State Research Foundation FAPERJ (E-26/102.852/2011 and E26/203.021/2015), The Brazilian National Council for Scientific and Technological Development CNPq (304144/2011-8 and 303426/2015-2), International Foundation for Science IFS (E/26223), Brazilian Post-Graduate Federal Agency CAPES, and Research and Project Financing Agency FINEP (23.01.0592.00).

RESUMO: Estudos sobre a cinética da secagem de plantas medicinais, aromáticas e condimentares são necessários para o estabelecimento de parâmetros operacionais de secagem de forma a não alterar significativamente a qualidade e o perfil fitoquímico dessas plantas. $\mathrm{O}$ objetivo do presente trabalho foi investigar a cinética da secagem das folhas da aroeira-vermelha (Schinus terebinthifolius), além de verificar se o modelo teórico de difusão e o modelo semi-empírico de Lewis são capazes de predizer com acurácia as curvas de secagem do produto a 35,40 e $45^{\circ} \mathrm{C}$, com fluxo de ar seco de $0,731 \mathrm{~kg} \mathrm{~s}^{-1} \mathrm{~m}^{-2}$. As folhas foram coletadas às 8:00, 12:00 e 17:00 h. O grau de adequação dos valores obtidos pelas curvas de secagem àqueles obtidos experimentalmente foi avaliado empregando-se o coeficiente de determinação, a raiz do erro quadrático médio, o erro percentual absoluto médio, o viés médio e o índice de ajuste. A análise da dispersão dos resíduos também foi utilizada na escolha do modelo de predição mais efetivo. Observou-se que a temperatura tem efeito significativo na transferência de massa e a taxa de secagem diminuiu continuamente ao longo da secagem. $\mathrm{O}$ horário de coleta das folhas não teve influência significativa sobre a cinética da secagem. A difusividade efetiva da água aumentou com o aumento da temperatura. Os resultados evidenciaram que o modelo de Lewis descreve com maior grau de acurácia a secagem de folhas de aroeira-vermelha que o modelo teórico baseado na Segunda Lei de Difusão de Fick.

PALAVRAS-CHAVE: Schinus terebinthifolius Raddi. Modelo de Lewis para secagem em camada delgada. Modelo teórico de secagem por difusão. Análise de erros.

\section{REFERENCES}

AKPINAR, E. K. Mathematical modelling of thin layer drying process under open sun of some aromatic plants. Journal of Food Engineering, v. 77, n. 4, p. 864-870, 2006. https://doi.org/10.1016/j.jfoodeng.2005.08.014

ARSLAN, D.; ÖZCAN, M. M.; MENGEŞ, H. O. Evaluation of drying methods with respect to drying parameters, some nutritional and colour characteristics of peppermint (Mentha x piperita L.). Energy

Conversion and Management, v. 51, n. 12, p. 769-775, 2010.

https://doi.org/10.1016/j.enconman.2010.06.013

ASABE Standards, S358.2: Moisture Measurement - Forages, 57th ed., American Society of Agricultural and Biological Engineers ASABE, St. Joseph, Mich., 2010.

BARBOSA, L. C. A.; DEMUNER, A. J.; CLEMENTE, A. D. Seasonal variation in the composition of volatile oils from Schinus terebinthifolius Raddi. Química Nova, v. 30, n. 8, p. 1959-1965, 2007. http://dx.doi.org/10.1590/S0100-40422007000800030 
BELGHIT, A.; KOUHILA, M.; BOUTALEB, B. C. Experimental study of drying kinetics by forced convection of aromatic plants. Energy Conversion and Management, v. 41, n. 12, p. 1303-1321, 2000. https://doi.org/10.1016/S0196-8904(99)00162-4

BENDAOUD, H.; ROMDHANE, M.; SOUCHARD, J. P.; CAZAUX, S.; BOUAJILA, J. Chemical composition and anticancer and antioxidant activities of Schinus molle L. and Schinus terebinthifolius Raddi berries essential oils. Journal of Food Science, v. 75, n. 6, p. C466-C472, 2010.

https://doi.org/10.1111/j.1750-3841.2010.01711.x

BLASCO, M.; GARCÍA-PÉREZ, J. V.; BON, J.; CARRERES J.E.; MULET, A. Effect of blanching and air flow rate on turmeric drying. Food Science and Technology International (London, United Kingdom), v. 12, n. 4, p. 315-323, 2006. https://doi.org/10.1177/1082013206067352

BROOKER, D. B.; BAKKER-ARKEMA, F. W.; HALL, C. W. Drying and Storage of Grains and Oilseeds. New York: Van Nostrand Reinhold, 450p., 1992.

BRUIN, S.; LUYBEN, K. Ch. A. M. Drying of food materials: A review of recent developments. In: MUJUMDAR, A. S. (Ed.). Advances in Drying - Vol. 1. Washington, DC: Hemisphere Publishing Corporation, pp. 155-215, 1980.

BUSER, M. D.; STONE, M. L.; BRUSEWITZ, G. H.; MANESS, N. O.; WHITELOCK, D. P. Thin-layer drying of marigold flowers and flower components for petal removal. Transactions of the ASAE, v. 42, n. 5, p. 1367-1373, 1999. https://doi.org/10.13031/2013.13299

BYLER, R. K.; ANDERSON, C. R.; BROOK, R. C. Statistical methods in thin layer parboiled rice drying models. Transactions of the ASAE, v. 30, n. 2, p. 533-538, 1987. https://doi.org/10.13031/2013.31983

CERUKS, M.; ROMOFF, P.; FÁVERO, O. A.; LAGO, J. H. G. Constituintes fenólicos polares de Schinus terebinthifolius Raddi (Anacardiaceae). Química Nova, v. 30, n. 3, p. 597-599, 2007.

http://dx.doi.org/10.1590/S0100-40422007000300018

CHENARBON, H. A.; MINAEI, S.; BASSIRI, A. R.; ALMASSI, M.; ARABHOSSEINI. A. Modeling of drying St. John's wort (Hypericum perforatum L.) leaves. Journal of Medicinal Plants Research, v. 5, n. 1, p. 126-132, 2011.

CRANK, J. The Mathematics of Diffusion, $2^{\text {nd }}$ ed., Oxford: Oxford University Press, 413 p., 1975.

D’AVILA, G.; GOMES-Jr, A.; CANARY, A. C.; BUGONI, L. The role of avian frugivores on germination and potential seed dispersal of the Brazilian Pepper Schinus terebinthifolius. Biota Neotropica, v. 10, n. 3, p. 45-51, 2010. http://dx.doi.org/10.1590/S1676-06032010000300004

DEMIR, V.; GUNHAN, T.; YAGCIOGLU, A. K.; DEGIRMENCIOGLU, A. Mathematical modelling and the determination of some quality parameters of air-dried bay leaves. Biosystems Engineering, v. 88, n. 3, p. 325335, 2004. https://doi.org/10.1016/j.biosystemseng.2004.04.005

DOYMAZ, I. Thin-layer drying behaviour of mint leaves. Journal of Food Engineering, v. 74, n. 3, p. 370375, 2006. https://doi.org/10.1016/j.jfoodeng.2005.03.009

DOYMAZ, I. Thin-layer drying of spinach leaves in a convective dryer. Journal of Food Process Engineering, v. 32, n. 1, p. 112-125, 2009. https://doi.org/10.1111/j.1745-4530.2007.00205.x

DOYMAZ, I.; TUGRUL, N.; PALA, M. Drying characteristics of dill and parsley leaves. Journal of Food Engineering, v. 77, n. 3, p. 559-565, 2006. https://doi.org/10.1016/j.jfoodeng.2005.06.070 
El-MASSRY, K. F.; El-GHORAB, A. H.; SHAABAN, H. A.; SHIBAMOTO, T. Chemical compositions and antioxidant/antimicrobial activities of various samples prepared from Schinus terebinthifolius leaves cultivated in Egypt. Journal of Agricultural and Food Chemistry, v. 57, n. 12, p. 5265-5270, 2009. https://doi.org/10.1021/jf900638c

ERTEKIN, C.; HEYBELI, N. Thin-layer infrared drying of mint leaves. Journal of Food Processing and Preservation, v. 38, n. 4, p. 1480-1490, 2014. https://doi.org/10.1111/jfpp.12107

EWE, S. M. L.; STERNBERG, L. S. L. Seasonal gas exchange characteristics of Schinus terebinthifolius in a native and disturbed upland community in Everglades National Park, Florida. Forest Ecology and Management, v. 179, n. 1-3, p. 27-36, 2003. https://doi.org/10.1016/S0378-1127(02)00531-5

FEUEREISEN, M. M.; HOPPE, J.; ZIMMERMANN, B. F.; WEBER, F.; SCHULZE-KAYSERS, N.; SCHIEBER, A. Characterization of phenolic compounds in Brazilian pepper (Schinus terebinthifolius Raddi) exocarp. Journal of Agricultural and Food Chemistry, v. 62, n. 26, p. 6219-6226, 2014. https://doi.org/10.1021/jf500977d

FORTES, M.; OKOS, M. R. Drying theories: Their bases and limitations as applied to foods and grains. In: MUJUMDAR, A. S. (Ed.). Advances in Drying - v. 1. Washington, DC: Hemisphere Publishing Corporation, pp. 119-154, 1980.

GONELI, A. L. D.; VIEIRA, M. C.; VILHASANTI, H. C. B.; GONÇALVES, A. A.; Modelagem matemática e difusividade efetiva de folhas de aroeira durante a secagem. Pesquisa Agropecuária Tropical, v. 44, n. 1, p. 56-64, 2014. http://dx.doi.org/10.1590/S1983-40632014000100005

GOYAL, R. K.; KINGSLY, A. R. P.; MANIKANTAN, M. R.; ILYAS, S. M. Thin-layer drying kinetics of raw mango slices. Biosystems Engineering, v. 95, n. 1, p. 43-49, 2006.

https://doi.org/10.1016/j.biosystemseng.2006.05.001

GUNHAN, T.; DEMIR, V.; HANCIOGLU, E.; HEPBASLI, A. Mathematical modelling of drying of bay leaves. Energy Conversion and Management, v. 46, n. (11-12), p. 1667-1679, 2005.

https://doi.org/10.1016/j.enconman.2004.10.001

HALL, D. W.; VANDIVER, V. V.; SELLERS, B. A.; LANGELAND, K. A. Brazilian Pepper-tree, Schinus terebinthifolius. University of Florida SP 37 Document. Gainesville: IIFAS Extension, 2012.

HANSEN, R. C.; KEENER, H. M.; ELSOHLY, H. N. Thin-layer drying of cultivated Taxus clippings.

Transactions of the ASAE, v. 36, n. 5, p. 1387-1391, 1993. https://doi.org/10.13031/2013.28475

KABGANIAN, R.; CARRIER, D. J.; SOKHANSANJ, S. Physical characteristics and drying rate of echinacea root. Drying Technology, v. 20, n. 3, p. 637-649, 2002. https://doi.org/10.1081/DRT-120002821

KADAM, D. M.; GOYAL, R. K.; SINGH, K. K.; GUPTA, M. K. Thin layer convective drying of mint leaves. Journal of Medicinal Plants Research, v. 5, n. 2, p. 164-170, 2011.

KAYA, A.; AYDIN, O. An experimental study on drying kinetics of some herbal leaves. Energy Conversion and Management, v. 50, n. 1, p. 118-124, 2009.

https://doi.org/10.1016/j.enconman.2008.08.024

LAHNINE, L.; IDLIMAM, A.; MAHROUZ, M.; MGHAZLI, S.; HIDAR, N.; HANINE, H.; KOUTIT, A. Thermophysical characterization by solar convective drying of thyme conserved by an innovative thermalbiochemical process. Renewable Energy, v. 94, p. 72-80, 2016.

https://doi.org/10.1016/j.renene.2016.03.014 
LEBERT, A.; THARRAULT, P.; ROCHA, T.; MARTY-AUDOUIN. C. The drying kinetics of mint (Mentha spicata Huds.). Journal of Food Engineering, v. 17, n. 1, p. 15-28, 1992.

https://doi.org/10.1016/0260-8774(92)90062-B

LEMUS-MONDACA, R.; VEGA-GÁLVEZ, A.; MORAGA, N. O.; ASTUDILLO, S.; Dehydration of Stevia rebaudiana Bertoni leaves: Kinetics, modeling and energy features. Journal of Food Processing and Preservation, v. 39, n. 5, p. 508-520, 2015. https://doi.org/10.1111/jfpp.12256

LENZI, M.; ORTH, A. I. Fenologia reprodutiva, morfologia e biologia floral de Schinus terebinthifolius Raddi (Anacardiaceae), em restinga da Ilha de Santa Catarina, Brasil. Biotemas, v. 17, n. 2, p. 67-89, 2004. https://doi.org/10.5007/\%25x

LEWIS, W. K. The rate of drying of solid materials. Journal of Industrial and Engineering Chemistry (Washington, D. C.), v. 13, n. 5, p. 427-432, 1921. https://doi.org/10.1021/ie50137a021

LIN, K. H.; Van NESS, H. C.; ABBOTT, M. M. Reaction kinetics, reactor design, and thermodynamics. In: PERRY, R. H.; CHILTON, C. H. (Eds.). Chemical Engineers' Handbook, New York: McGraw-Hill, pp. 4.14.75, 1973.

MADAMBA, S. P.; DRISCOLL, H. R.; BUCKLE, K. A. The thin-layer drying characteristics of garlic slices. Journal of Food Engineering, v. 29, n. 1, p. 75-97, 1996.

https://doi.org/10.1016/0260-8774(95)00062-3

MADHIYANON, T.; PHILA, A.; SOPONRONNARIT, S. Models of fluidized bed drying for thin-layer chopped coconut. Applied Thermal Engineering, v. 29, n. 14-15, p. 2849-2854, 2009.

https://doi.org/10.1016/j.applthermaleng.2009.02.003

MARTINAZZO, A. P.; MELO, E. C.; CORRÊA, P. C.; SANTOS, R. H. S. Modelagem matemática e parâmetros qualitativos da secagem de folhas de capim limão [Cymbopogon citratus (DC.) Stapf]. Revista Brasileira de Plantas Medicinais, v. 12, n. 4, p. 488-498, 2010.

http://dx.doi.org/10.1590/S1516-05722010000400013

Mc KAY, F.; OLEIRO, M.; WALSH, G. C.; GANDOLFO, D.; CUDA, J. P.; WHEELER, G. S. Natural enemies of Brazilian peppertree (Sapindales: Anacardiaceae) from Argentina: Their possible use for biological control in the USA. Florida Entomologist, v. 92, n. 2, p. 292-303, 2009.

https://doi.org/10.1653/024.092.0213

MELO, E. C.; LOPES, D. C.; CORRÊA, P. C. GRAPSI - Programa computacional para o cálculo das propriedades psicrométricas do ar. Engenharia na Agricultura, v. 12, n. 2, p. 154-162, 2004.

MILLS, I.; CVITAŠ, T.; HOMANN, K.; KALLAY, N.; KUCHITSU, K. International Union of Pure and Applied Chemistry: Quantities, Units and Symbols in Physical Chemistry, Boca Raton: Blackwell Science, 167p., 1993. https://old.iupac.org/publications/books/gbook/green_book_2ed.pdf

MORGAN, E. C.; OVERHOLT, W. A. Potential allelopathic effects of Brazilian pepper (Schinus terebinthifolius Raddi, Anacardiaceae) aqueous extract on germination and growth of selected Florida native plants. Journal of the Torrey Botanical Society, v. 132, n. 1, p. 11-15, 2005. https://doi.org/10.3159/10955674(2005)132[11:PAEOBP]2.0.CO;2

MORTON, J. Brazilian pepper - Its impact on people, animals and the environment. Economic Botany, v. 32, n. 4, p. 353-359, 1978. https://doi.org/10.1007/BF02907927

MOTA, C. L.; LUCIANO, C.; DIAS, A.; BARROCA, M. J.; GUINÉ, R. P. F. (2010). Convective drying of onion: Kinetics and nutritional evaluation. Food and Bioproducts Processing, v. 88, n. 2-3, p. 115-123, 2010. https://doi.org/10.1016/j.fbp.2009.09.004 
MOURA, E. E.; BERBERT, P. A.; BERBERT-MOLINA, M. A.; OLIVEIRA, M. T. R. Performance analysis of RF dielectric models for density-independent estimation of moisture content in sorghum. Powder Technology, v. 246, p. 369-378, 2013. https://doi.org/10.1016/j.powtec.2013.04.030

OLIVEIRA, M. T. R.; BERBERT, P. A.; MARTINAZZO, A. P. Avaliação de modelos matemáticos na descrição das curvas de secagem por convecção de Pectis brevipedunculata (Gardner) Sch. Bip. Revista Brasileira de Plantas Medicinais, v. 15, n. 1, p. 1-12, 2013.

http://dx.doi.org/10.1590/S1516-05722013000100001

OLIVEIRA, M. T. R.; BERBERT, P. A.; MARTINAZZO, A. P.; BERBERT-MOLINA, M. A. Drying kinetics of lemon-scented grass. Transactions of the ASABE, v. 54, n. 5, p. 1837-1846, 2011.

https://doi.org/10.13031/2013.39823

OMID, M.; BAHARLOOEI, A.; AHMADI, H. Modeling drying kinetics of pistachio nuts with multilayer feedforward neural network. Drying Technology, v. 27, n. 10, p. 1069-1077, 2009.

https://doi.org/10.1080/07373930903218602

OZGUVEN, M. M.; TARHAN, S.; POLATCI, H.; TELCI, I. A new way to improve the drying kinetics and final quality of peppermint. Journal of Essential Oil-Bearing Plants, v. 19, n. 6; p. 1368-1379, 2016. https://doi.org/10.1080/0972060X.2016.1205522

PANCHARIYA, P. C.; POPOVIC, D.; SHARMA, A. L. Thin-layer modelling of black tea drying process. Journal of Food Engineering, v. 52, n. 4, p. 349-357, 2002.

https://doi.org/10.1016/S0260-8774(01)00126-1

PIN, K. Y.; CHUAH, T. G.; RASHIH, A. A.; LAW, C. L.; RASADAH, M. A.; CHOONG, T.S.Y. Drying of betel leaves (Piper betle L.): Quality and drying kinetics. Drying Technology, v. 27, n. 1, 149-155, 2009. https://doi.org/10.1080/07373930802566077

PORTER, H. F.; McCORMICK, P. Y.; LUCAS, R. L.; WELLS, D. F. Gas-Solid systems. IN: PERRY, R. H.; CHILTON, C. H. (Eds.). Chemical Engineers' Handbook, New York: McGraw-Hill, pp.20.1-20.121, 1973.

RADÜNZ, L. L.; MELO, E. C.; ROCHA, R. P.; BARBOSA, F. F.; SANTOS, R. H. S.; BERBERT, P. A. Avaliação das curvas de secagem de guaco (Mikania glomerata Spreng.) em secador de bandejas. Revista Brasileira de Plantas Medicinais, v. 16, n. 2, p. 378-387, 2014. https://doi.org/10.1590/1983-084X/10_128

RODRÍGUEZ, J.; CLEMENTE, G.; SANJUÁN, N; BOM, J. Modelling drying kinetics of thyme (Thymus vulgaris L.): Theoretical and empirical models, and neural networks. Food Science and Technology

International (London, United Kingdom), v. 20, n. 1, p. 13-22, 2014.

https://doi.org/10.1177/1082013212469614

SACILIK, K.; UNAL, G. Dehydration characteristics of Kastamonu garlic slices. Biosystems Engineering, v. 92, n. 2, p. 207-215, 2005. https://doi.org/10.1016/j.biosystemseng.2005.06.006

SAKKALKAR, S. R.; BAKANE, P. H.; KHEDKAR, M. B.; DHUMAL, C. V. Modeling of convective drying of safed musli (Chlorophytum borivilinum). Journal of Medicinal Plants Research, v. 7, n. 10, p. 602-611, 2013. https://doi.org/10.1590/1983-084X/10_128

SILVA, A. S.; ALMEIDA, F. A. C.; LIMA, E. E.; SILVA, F. L. H.; GOMES, J. P. Drying kinetics of coriander (Coriandrum sativum) leaf and stem. Ciência e Tecnologia de Alimentos, v. 6, n. 1, p. 13-19, 2008. https://doi.org/10.1080/11358120809487622

SILVA, F. P.; SIQUEIRA, V. C.; MARTINS, E. A. S.; MIRANDA, F. M. N.; MELO, R. M. Thermodynamic properties and drying kinetics of Bauhinia forficata Link leaves. Revista Brasileira de Engenharia Agrícola e Ambiental, v. 21, n. 1, p. 61-67, 2017. https://doi.org/10.1590/1807-1929/agriambi.v21n1p61-67 
SOUSA, A. D.; RIBEIRO, P. R. V.; CANUTO, K. M.; ZOCOLO, G. J.; PEREIRA, R. C. A.; FERNANDES, F. A. N. Drying kinetics and effect of air-drying temperature on chemical composition of Phyllanthus amarus and Phyllanthus niruri. Drying Technology, v. 36, n. 5, p. 609-616, 2018.

https://doi.org/10.1080/07373937.2017.1351454

SPIESS, W. E. L.; WOLF, W. Critical evaluation of methods to determine moisture sorption isotherms. In: ROCKLAND, L. B.; BEUCHAT L. R. (Eds). Water Activity: Theory and Applications to Food, New York: Marcel Dekker, Inc., pp. 215-233, 1987.

TEMPLE, S. J.; van BOXTEL, A. J. B. Thin layer drying of black tea. Journal of Agricultural Engineering Research, v. 74, n. 2, p. 167-176, 1999. https://doi.org/10.1006/jaer.1999.0448

THERDTHAI, N.; ZHOU, W. Characterization of microwave vacuum drying and hot air drying of mint leaves (Mentha cordifolia Opiz ex Fresen). Journal of Food Engineering, v. 91, n. 3, p. 482-489, 2009. https://doi.org/10.1016/j.jfoodeng.2008.09.031

TOĞRUL, İ. T.; PEHLIVAN, D. Modelling of drying kinetics of single apricot. Journal of Food Engineering, v. 58, n. 1, p. 23-32, 2003. https://doi.org/10.1016/S0260-8774(02)00329-1

WILLIAMS, D. A.; OVERHOLT, W. A.; CUDA, J. P.; HUGHES, C. R. Chloroplast and microsatellite DNA diversities reveal the introduction history of Brazilian peppertree (Schinus terebinthifolius) in Florida.

Molecular Ecology, v. 14, n. 12, p. 3643-3656, 2005. https://doi.org/10.1111/j.1365-294X.2005.02666.x

WILLMOTT, C. J. Some comments on the evaluation of model performance. Bulletin of the American Meteorological Society, v. 63, n. 11, p. 1309-1313, 1982.

https://doi.org/10.1175/1520-0477(1982)063<1309:SCOTEO>2.0.CO;2

ZANOELO, E. F.; Di CELSO, G. M.; KASKANTZIS, G. Drying kinetics of mate leaves in a packed bed dryer. Biosystems Engineering, v. 96, n. 4, p. 487-494, 2007.

https://doi.org/10.1016/j.biosystemseng.2006.12.006

\section{ANNEX}

\section{NOMENCLATURE}

\begin{tabular}{|c|c|c|}
\hline$D_{\text {eff }}$ & $=$ & effective water diffusivity $\left(\mathrm{m}^{2} \mathrm{~s}^{-1}\right)$ \\
\hline $\mathrm{D}_{0}$ & $=$ & water diffusivity at infinitely high temperature $\left(\mathrm{m}^{2} \mathrm{~s}^{-1}\right)$ \\
\hline d.m. & $=$ & dry matter \\
\hline k & $=$ & drying constant $\left(\mathrm{h}^{-1}\right)$ \\
\hline $\mathrm{E}_{\mathrm{a}}$ & $=$ & activation energy $\left(\mathrm{kJ} \mathrm{mol}^{-1}\right)$ \\
\hline L & $=$ & half thickness of an infinite slab when mass transfer occurs on its both sides \\
\hline MR & $=$ & moisture ratio (dimensionless) \\
\hline $\mathrm{MR}_{\mathrm{est}}$ & $=$ & model-estimated moisture ratio (dimensionless) \\
\hline $\mathrm{MR}_{\text {exp }}$ & $=$ & experimental moisture ratio (dimensionless) \\
\hline$\overline{\mathrm{MR}}_{\exp }$ & $=$ & mean experimental moisture ratio (dimensionless) \\
\hline M & $=$ & moisture content ( $\mathrm{kg} \mathrm{H}_{2} \mathrm{O} / \mathrm{kg} \mathrm{d.m.)}$ \\
\hline $\mathrm{M}_{0}$ & $=$ & initial moisture content ( $\mathrm{kg} \mathrm{H}_{2} \mathrm{O} / \mathrm{kg} \mathrm{d}$ d.m.) \\
\hline$M_{e}$ & $=$ & equilibrium moisture content ( $\mathrm{kg} \mathrm{H}_{2} \mathrm{O} / \mathrm{kg} \mathrm{d.m}$.) \\
\hline$M_{t}$ & $=$ & moisture content at any time $\mathrm{t}\left(\mathrm{kg} \mathrm{H}_{2} \mathrm{O} / \mathrm{kg} \mathrm{d}\right.$.m.) \\
\hline $\mathrm{n}$ & $=$ & number of terms employed to calculate MR with the diffusion equation \\
\hline $\mathrm{N}$ & & number of experimental moisture content measurements at each drying run \\
\hline & $=$ & coefficient of determination (dimensionless) \\
\hline & $=$ & universal gas constant $\left(8.31451 \mathrm{~J} \mathrm{~K}^{-1} \mathrm{~mol}^{-1}\right)$ (Mills et al., 1993) \\
\hline RMSE & $=$ & root mean square error (dimensionless) \\
\hline
\end{tabular}


Thin-layer convective...

$\begin{array}{lll}\mathrm{t} & = & \text { drying time }(\mathrm{h}) \\ \mathrm{T}_{\mathrm{abs}} & = & \text { absolute dry-bulb temperature }(\mathrm{K}) \\ \delta & = & \text { fit index or index of agreement between experimental and estimated values (dimensionless) } \\ \eta & =\text { mean absolute percentage error }(\%) \\ \xi & =\text { mean bias (dimensionless) } \\ \zeta, \partial \mathrm{M} / \partial \mathrm{t} & =\text { drying rate }\left(\mathrm{kg} \mathrm{H} \mathrm{H}_{2} \mathrm{O} / \mathrm{kg} \mathrm{d.m.} \mathrm{h}\right)\end{array}$

